\title{
Improved Fertiliser Management To Reduce The Greenhouse-Gas Emissions And Ensure Yields In A Wheat-Peanut Rotation System In China
}

Zhaoxin Liu ( $\square$ liuxiaoxin0110@163.com )

Shandong Agricultural University

Chen Zhao

Shandong Agricultural University

Jihao Zhao

Shandong Agricultural University

Huajiang Lai

Shandong Agricultural University

Xiangdong Li

Shandong Agricultural University

\section{Research Article}

Keywords: $\mathrm{N}$ management, greenhouse gas, wheat-peanut relay intercropping, global warming potential, crop yield

Posted Date: September 20th, 2021

DOI: https://doi.org/10.21203/rs.3.rs-843057/v1

License: (c) (1) This work is licensed under a Creative Commons Attribution 4.0 International License. Read Full License 


\section{Abstract}

Over the last century, anthropogenic greenhouse-gas (GHG) emissions have changed the global climate, and agriculture plays an important role in the global flux of GHG. Agricultural management practices, such as split $\mathrm{N}$ applications and the use of controlled-release fertilisers have significantly increased the crop yield and $\mathrm{N}$-use efficiency by balancing the $\mathrm{N}$ demand of crops and the $\mathrm{N}$ availability of soils. However, the impacts of these practices on GHG emissions (in particular in wheat-peanut relay intercropping systems) have not been evaluated in detail. In this study, we used a common compound fertiliser and a controlled-release compound fertiliser (CRF) applied the day prior to sowing, at the jointing stage of wheat, and at the anthesis stage of peanut in various proportions, with a control treatment of 0 $\mathrm{kg} \mathrm{ha}^{-1}$. The findings demonstrated that treatment JCF70 achieved increases in yields of $9.7 \%$ and $14.6 \%$ for wheat grain and peanut pod, respectively, compared to treatment JCF100; however, this treatment also significantly increased soil emissions of $\mathrm{CO}_{2}$ and $\mathrm{N}_{2} \mathrm{O}$. In addition, cumulative emissions of $\mathrm{CO}_{2}$ and $\mathrm{N}_{2} \mathrm{O}$ were higher in the peanut growing season by 74.4 and $31.7 \%$, respectively, than in the wheat growing season owing to the relatively higher soil temperature during the former season. Fertilisation combined with irrigation, was found to be the main cause of GHG emissions. Under the same fertiliser rate and Nmanagement style, JCRF70 further increased the yield of peanut pods and the total combined yield of peanut and wheat by $10.3 \%$ and $8.9 \%$, respectively, compared to treatment JCF70. The cumulative $\mathrm{CO}_{2}$ and $\mathrm{N}_{2} \mathrm{O}$ emissions in treatment JCRF70 were $20.4-45.4 \%$ less than those in treatment JCF70. The total global warming potentials of $\mathrm{CO}_{2}$ and $\mathrm{N}_{2} \mathrm{O}$ were lowest in treatment JCRF70 owing to it providing the highest grain yield. Therefore, $\mathrm{N}$ application with three splits, together with the use of a slow-release fertiliser, may be a simple and effective approach to enhance the grain yield while reducing the GHG emissions.

\section{Introduction}

Global climate change has been shown to largely result from rising emissions of greenhouse gas (GHG) (IPCC, 2013). The use of mineral nitrogen $(\mathrm{N})$ fertiliser is amongst the largest contributors to emissions of GHG from agricultural production systems, particularly in China (IPCC, 2007; Rochette et al., 2008). Due to China's growing population and limited arable land, chemical fertilisers have been used at an increasing rate to meet agricultural demands (FAO, 2010), however, most research has found that $\mathrm{CO}_{2}$ emissions increase exponentially with increased $\mathrm{N}$ application rate and when $\mathrm{N}$ availability exceeds plant demand (Zhong et al., 2016; Dossou-Yovo et al., 2016). In agriculture, the increase in chemical fertilisation not only causes direct economic losses but also increases nitrate (NO-3) leaching and emissions of $\mathrm{N}_{2} \mathrm{O}$, which is an important greenhouse gas whose global warming potential (GWP) is 298 times that of $\mathrm{CO}_{2}$ (Chen and Zhang, 2010; IPCC, 2013; Xiao et al., 2019; Puga et al., 2020). Therefore, developing ways to reduce agricultural GHG emissions is urgently required.

The North China Plain (NCP) provides around $68 \%$ of China's total grain yield of wheat (Triticum aestivum L.) (Wang et al., 2009) and contains around 60\% of China's farmlands that produce peanuts (Arachis 
hypogaea L.) (Guo et al., 2010). In the NCP, wheat-peanut relay intercropping systems are widely used to produce more food for the increasing population. In such systems, local farmers typically apply $100 \%$ of the fertiliser in the wheat growing stage since peanut plants are known for their capacity to convert atmospheric nitrogen $\left(\mathrm{N}_{2}\right)$ into a usable form of $\mathrm{N}$ (Zhang et al., 2016). For wheat, the mean $\mathrm{N}$ application level is around $300 \mathrm{~kg} \mathrm{ha}^{-1}$ (Ma et al., 2015). However, a level of $240 \mathrm{~kg} \mathrm{~N} \mathrm{ha}^{-1}$ was suggested to achieve adequate grain yield and $\mathrm{N}$ utilisation efficiency (NUE) (Li et al., 2011). Due to the different $\mathrm{N}$ demands of plants in different growth stages, excess nitrogen may not only reduce the NUE of crops but may also increase the amount of $\mathrm{N}$ that is lost to the environment and may thus contribute to pollution in the atmosphere and in aquatic systems (Guo et al., 2010; Wang et al., 2016). A previous study found that excessive nitrogen could immediately increase the soil NO- 3-N contents to a level exceeding the range of crop absorption and utilization at this stage and could produce $\mathrm{N}_{2} \mathrm{O}$ through nitrification via the oxidation of ammonia $\left(\mathrm{NH}_{3}\right)$ to nitrite (NO-2-N) Zebarth et al. (2012). Additionally, although peanuts, as legumes, can fix nitrogen from $\mathrm{N}_{2}$, more than half of the nitrogen needs to be obtained from soil and fertiliser, and a moderate supply of nitrogen can promote the growth of peanut root nodules (Wang et al., 2016). Therefore, nitrogen fertilisation strategies should be improved to obtain high yield in wheat-peanut relay intercropping systems.

Improved fertilisation management can also increase fertiliser NUE and reduce GHG emissions (Liu et al., 2015). Split $\mathrm{N}$ fertiliser applications, adjusted ratios of basal-N to top-dressed $\mathrm{N}$, and the application of controlled-release fertiliser (CRF) have been proposed as means to decrease $\mathrm{N}_{2} \mathrm{O}$ emissions (Akiyama et al., 2010; Ye et al., 2013). Specifically, for a given total $\mathrm{N}$ rate, when the rate of $\mathrm{N}$ fertiliser application is kept low through split application, lower cumulative $\mathrm{CO}_{2}$ emissions would be expected relative to a single application. Split application of $\mathrm{N}$ fertiliser has been demonstrated to increase the synchronicity between the $\mathrm{N}$ demand of crops and soil-N availability, and can therefore improve the NUE (Ribaudo et al., 2011). Past research has investigated the impact of split $\mathrm{N}$ application and the timing of $\mathrm{N}$ application on $\mathrm{GHG}$ emissions; however, consistent results have not been obtained (Zebarth et al., 2012; Wang et al., 2016; Liang et al., 2017). Yan et al. (2001) and Burton et al. (2008) studied the impact of split $\mathrm{N}$ application on $\mathrm{N}_{2} \mathrm{O}$ emission and found that split or delayed application of $\mathrm{N}$ could obtain lower or equivalent cumulative $\mathrm{N}_{2} \mathrm{O}$ emissions than a single early $\mathrm{N}$ application; however, no significant effect was found in the second year. Additionally, in a rain-fed potato experiment, Zebarth et al. (2012) showed that, although split $\mathrm{N}$ application led to a significant reduction in the nitrate exposure, it did not mitigate the $\mathrm{N}_{2} \mathrm{O}$ emissions from medium-textured soil. Furthermore, a study on maize production using plastic mulching in a semiarid region indicated that $\mathrm{N}$ application at a 4:3:3 ratio at the six-leaf, ten-leaf, and grain-filling stages carried a higher risk of increasing $\mathrm{N}_{2} \mathrm{O}$ emissions compared to the application of $\mathrm{N}$ at a 4:6 ratio at the six-leaf and ten-leaf stages. This was as a result of the strong and frequent rainfall in the middle and late growing stages of maize (Wang et al., 2016). Moreover, Venterea and Coulter (2015) showed that the split application of granular urea to meet crop $\mathrm{N}$ demand did not always reduce, and sometimes increased, emissions of $\mathrm{N}_{2} \mathrm{O}$. These conflicting findings may reflect the potential sensitivity of soil 
emissions of $\mathrm{N}_{2} \mathrm{O}$ to a wide range of factors that can affect $\mathrm{N}_{2} \mathrm{O}$ production, such as factors related to management, the environment, and soil (Venterea et al., 2012).

New technologies employing CRF are emerging as excellent ways to improve nutrient application and thus to significantly reduce environmental risks while achieving high-quality crop yields (Shi et al., 2013). Chi et al. (2020) investigated the impacts of urea, amine, and CRF on soil $\mathrm{CO}_{2}$ emissions in wheat-maize rotations and found that the use of CRF was associated with lower $\mathrm{CO}_{2}$ emissions and higher yield. Additionally, there is increasing evidence that CRF can be used to control the timing of $\mathrm{N}$ release from fertiliser. Therefore, the application of CRF in agricultural production can significantly decrease $\mathrm{N}$ losses from leaching in NO- 3-N via the volatilisation of $\mathrm{NH}_{3}$ and via the emission of $\mathrm{N}_{2} \mathrm{O}$ (Shaviv, 2001; McTaggart and Tsuruta, 2003). However, contradictory results have been obtained regarding the potential of CRF to lower GHG emissions from upland soils in different locations. For example, Ball (2004) reported that $\mathrm{CRF}$ reduced the high initial $\mathrm{N}_{2} \mathrm{O}$ flux after heavy rainfall but did not significantly mitigate fluxes of $\mathrm{CO}_{2}$ or $\mathrm{CH}_{4}$ under silage production. Additionally, Yan et al. (2000) found that the ability of CRF to reduce $\mathrm{N}_{2} \mathrm{O}$ emissions from paddy soil was balanced by the increased release of $\mathrm{NH}+4-\mathrm{N}$ in the mid-season aeration stage. Meanwhile, Li et al. (2004) found that CRF significantly decreased cumulative $\mathrm{N}_{2} \mathrm{O}$ emissions from a rice field due to its regulation of the timing of $\mathrm{N}$ release.

Several studies have investigated the impacts of $\mathrm{N}$ fertilisation strategies on GHG emissions from wheat (Liu et al., 2011) and maize (Wang et al., 2016) cropping systems in Central China. However, only a few such studies have been conducted on peanut fields. Furthermore, the majority of the previously mentioned studies involved only single-season cropping systems, while a few focused on wheat-peanut relay intercropping systems in the NCP. The goals of this research were to (1) determine the seasonal changes of the NH+4-N and NO- 3-N content of soil and GHG emissions in wheat-peanut relay intercropping systems over the entire year, (2) analyse the effects of split application of $\mathrm{N}$ on the crop yields and cumulative emissions of $\mathrm{CO}_{2}$ and $\mathrm{N}_{2} \mathrm{O}$ in both the wheat and peanut growing seasons, and (3) quantify the combined impacts of split $\mathrm{N}$ application and the use of CRF on the global warming potential (GWP) and global warming potential intensity (GHGI). We hypothesised that split $\mathrm{N}$ application in combination with CRF would reduce the GHG emissions without sacrificing crop yields in a wheatpeanut relay intercropping system in China.

\section{Materials And Methods}

\subsection{Experimental area, design, and treatment}

Field experiments were performed at the experimental farm of Shandong Agricultural University, Taian, Shandong Province, China, in the NCP (36 09' N, 11709' E) from 2017 to 2019 . The study site experiences a temperate continental monsoon climate. The total precipitation during the wheat growth period was $182.6 \mathrm{~mm}$ in 2017-2018 and $104.2 \mathrm{~mm}$ in 2018-2019, and those during the peanut growth periods were $532.3 \mathrm{~mm}$ and $366.8 \mathrm{~mm}$, respectively (Fig. 1). The soil at the experimental farm is sandy 
loam (Cambisols; FAO/EC/ISRIC, 2003). The soil properties for a depth of $0-20 \mathrm{~cm}$ were as follows: $\mathrm{pH}$, 8.13; organic matter, $12.7 \mathrm{~g} \mathrm{~kg}^{-1}$; total $\mathrm{N}, 0.96 \mathrm{~g} \mathrm{~kg}^{-1}$; available phosphorus (Olsen-P), $45.1 \mathrm{mg} \mathrm{kg}^{-1}$; and available potassium $\left(\mathrm{NH}_{4} \mathrm{OAc}-\mathrm{K}\right), 83.1 \mathrm{mg} \mathrm{kg}^{-1}$.

The experimental design involved an entirely randomised block with three replicates. Plots were spaced by $3 \mathrm{~m} \times 3 \mathrm{~m}$ concrete wall barriers that acted as water barriers. In this study, the $\mathrm{N}, \mathrm{P}_{2} \mathrm{O}_{5}$, and $\mathrm{K}_{2} \mathrm{O}$ contents of both the common compound fertiliser (CCF) and the CRF were $20 \%, 15 \%$, and $10 \%$, respectively, and three splits fertiliser application at a rate of $1500 \mathrm{~kg} \mathrm{ha}^{-1}\left(300 \mathrm{~kg} \mathrm{ha}^{-1}\right.$ pure N) was the main factor that was studied. A N fertiliser was used prior to sowing, at the jointing stage of wheat, and at the anthesis stage of peanuts at ratios of 50-50-0\% (JCF100), 35-35-30\% (JCF70), and 35-35-30\% (JCRF70), with a control (CK) of $0 \mathrm{~kg} \mathrm{~N}^{-1}$. Details of the different treatments are provided in Table 1 and Fig. 2. For base $\mathrm{N}$, a $\mathrm{N}$ fertiliser was manually spread across the soil surface before sowing and was then ploughed into the soil, while for top-dressed N, a N fertiliser was added in bands in the centre of the rows at a depth of $5 \mathrm{~cm}$ for both winter wheat and peanuts. Winter-wheat variety Jimai 22 and peanut variety Shanhua 101 were used. Wheat was sown in the plots in nine rows with a row spacing of $30 \mathrm{~cm}$, and peanuts were sown between the winter wheat rows 15-20 days before wheat harvesting with a spacing of $22 \mathrm{~cm}$ between plants (Fig. 2). Diseases, weeds, and pests were adequately controlled in all the treatments.

Table 1

$\mathrm{N}$ application stages and fertiliser ratios during the wheat and peanut growing seasons

\begin{tabular}{|lllll|}
\hline Treatment & & Wheat & Peanut \\
\cline { 3 - 5 } & & Basal & Jointing stage & Initial flowering stage \\
\hline & Urea type & Fertiliser ratio $(\%)$ & Fertiliser ratio $(\%)$ & $\begin{array}{l}\text { Fertiliser ratio } \\
(\%)\end{array}$ \\
\hline CK & & & 0 \\
\hline JCF100 & CCF & 50 & 0 & 0 \\
\hline JCF70 & CCF & 35 & 50 & 30 \\
\hline JCRF70 & CRF & 35 & 35 & 30 \\
\hline
\end{tabular}

CCF: common compound fertiliser; CRF: controlled release compound fertiliser; \%: proportion of total fertiliser applied

\subsection{Measurement of GHG emissions}

The flux of greenhouse gases was analysed using static chamber-gas chromatography. The length, width, and height of the static chambers were 30,30 , and $40 \mathrm{~cm}$, respectively. A pedestal $(50 \times 50 \times 20$ $\mathrm{cm}$ ) with a water-filled groove was placed under the static chamber to maintain an airtight seal in the top chamber during the air-extraction process. The pedestal were inserted in the soil at a depth of $20 \mathrm{~cm}$ after 
application the basal fertiliser, one row wheat were sown near the edge in the pedestal and the number of wheat seeds was calculated according to design and the inner wheat row in the pedestal is consistent with in the field. Peanut was sown in the winter wheat rows and one peanut plant were included in the chambers after wheat harvest. The pedestal was removed prior to and reinstalled after top-dressed fertiliser at the same site. Additional chambers $(50 \times 50 \times 80 \mathrm{~cm})$ were used between jointing and harvest to adapt the height of the growing wheat plants at this stage. To minimise internal temperature changes, each chamber was coated with Styrofoam. The chambers contained a sampling outlet in the top portion of the lateral plane, and small fans were placed in the upper part of each chamber to guarantee the full mixing of air within the chamber. One chamber was placed in each plot, with a total of three replicates per treatment.

The first sampling was performed immediately after the basal fertiliser application of wheat and the following samplings were conducted once a week thereafter until peanut harvest. An additional collection every day for one week was conducted after the second and third fertilisations. Gas samples were acquired between 09:00 a.m. and 11:00 a.m. local time with a $50 \mathrm{~mL}$ polypropylene syringe $0,10,20$, and 30 min following chamber deployment. The gas was then transferred to a $100 \mathrm{~mL}$ aluminium-foil gassampling bag. The temperature inside the chamber and the humidity in the upper $20 \mathrm{~cm}$ of soil were recorded and monitored during gas collection. The GHG concentrations were analysed on the day of sampling with an Agilent 7890A gas chromatograph (Agilent Technologies, Inc., Shanghai, China) fitted with an electron capture detector (ECD) and a flame ionisation detector (FID).

$\mathrm{F}=\rho \times \mathrm{V} / \mathrm{A} \times \mathrm{dc} / \mathrm{dt} \times 273 /(273+\mathrm{T})(1)$

where $\mathrm{F}$ is the gas emission flux $\left(\mathrm{CO}_{2}\right.$ in $\mathrm{mg} \mathrm{m}^{-2} \mathrm{~h}^{-1}, \mathrm{~N}_{2} \mathrm{O}$ in $\left.\mu \mathrm{g} \mathrm{m}^{-2} \mathrm{~h}^{-1}\right) ; \rho$ is the gas density in the standard state $\left(\mathrm{kg} \mathrm{m}^{-3}\right) ; \mathrm{V}$ is the volume of the static chamber $\left(\mathrm{m}^{3}\right) ; \mathrm{A}$ is the bottom area of the static chamber $\left(\mathrm{m}^{2}\right)$; dc/dt is the slope of the line of the change in gas concentration over time; and $\mathrm{T}$ is the air temperature in the static chamber.

The cumulative emissions of $\mathrm{CO}_{2}$ and $\mathrm{N}_{2} \mathrm{O}$ in both the wheat and peanut growing seasons were determined according Singh et al. (1999) as follows:

$E_{\mathrm{CO} 2}$ or $E_{\mathrm{N} 20}=\sum\left[\left(F_{\mathrm{i}+1}+F_{\mathrm{i}}\right) / 2\right] \times\left(\mathrm{D}_{\mathrm{i}+1}-\mathrm{D}_{\mathrm{i}}\right) \times 24 / 1000(2)$

\subsection{Global warming potential (GWP) and global warming potential intensity (GHGI)}

To calculate the global warming potential (GWP) under different agricultural regimes, the GWP of $\mathrm{N}_{2} \mathrm{O}$ was considered to be 298 times that of $\mathrm{CO}_{2}$ (IPCC, 2013).

$\mathrm{GWP}=\left(\mathrm{N}_{2} \mathrm{O}\right.$ emission $\left.\times 298\right)+\mathrm{CO}_{2}$ emission (3) 
The global warming potential intensity (GHGI) was obtained by dividing the GWP by the grain yield (Shang et al., 2011):

GHGI $\left(\mathrm{ka} \mathrm{ha}^{-1}\right)=\frac{\text { GWP }\left(\mathrm{ka} \mathrm{ha}^{-1}\right)}{\text { Yield }\left(\mathrm{kg} \mathrm{ha}^{-1}\right)}$

\subsection{Measurement of $\mathrm{NH}+4-\mathrm{N}$ and NO- 3-N}

Fresh samples of soil ( $60 \mathrm{~cm}$ in length by $20 \mathrm{~cm}$ in depth) were extracted from each plot using an earth drill at 15-day intervals from 2018-2019. Samples were extracted from depths of 0-20, 20-40, and 40$60 \mathrm{~cm}$, and each sample was transferred to a Ziploc bag for the measurement of ammonium $(\mathrm{NH}+4-\mathrm{N})$ and nitrate (NO- 3-N) concentrations. Soil concentrations of NH + 4-N and nitrate NO- 3-N were measured using $25 \mathrm{~mL}$ of $1-\mathrm{M} \mathrm{KCl}$ solution. Then, the solution was filtered using a $0.45 \mu \mathrm{m}$ membrane filter to extract insoluble particulates, and the concentration was determined using a continuous flow analyser. The soil moisture content was measured gravimetrically by drying the subsamples at $105^{\circ} \mathrm{C}$ for $24 \mathrm{~h}$. The soil water-filled pore space (WFPS) was determined after Beare et al. (2009) as follows:

$\operatorname{WFPS}(\%)=\frac{\mathrm{W}}{1-\mathrm{r} / 2.65} \times r \times 100$

where $\mathrm{W}$ is the soil water content (\%), and $\mathrm{r}$ is the soil bulk density.

\subsection{Statistical data analysis}

All data were analysed by ANOVA using the DPS software (version 7.05; Hangzhou RuiFeng Information Technology Co., Hangzhou, China). The statistically significant differences between treatments were determined by the least significant difference test (LSD) at the $\mathrm{P}<0.05$ level. The wheat and peanut yield dates reported in this study were measured over 2017-2019. The data were plotted using the SigmaPlot 10.0 software (Systat Software, San Jose, CA, USA).

\section{Results}

\subsection{Environmental variables and soil condition}

The daily air temperature and precipitation, as well as soil temperature and WFPS, are shown in Figure 1. Strong precipitation occurred during the peanut growing season, especially in August. The daily average air temperature during the wheat growing season ranged from -6.9 to $28.8^{\circ} \mathrm{C}$ in $2017-2018$ and from -4.8 to $29.3^{\circ} \mathrm{C}$ in $2018-2019$, and those during the peanut growing season ranged from 21.2 to $31.8^{\circ} \mathrm{C}$ and from 21.1 to $31.5^{\circ} \mathrm{C}$, respectively (Fig. $1 \mathrm{~A}, \mathrm{~B}$ ). The seasonal variation trend of soil temperature was comparable to that of air temperature, ranging from 4.8 to $26.7^{\circ} \mathrm{C}$ in the wheat growing season and from 21.1 to $31.5^{\circ} \mathrm{C}$ in the peanut growing season (Fig. 1C). The mean seasonal soil temperature in the peanut growing season was $13.8^{\circ} \mathrm{C}$ greater than that in the wheat growing season. The soil WFPS significantly increased after irrigation and heavy rainfall. There was no significant difference in soil WFPS between the various fertilisation rates. However, the soil WFPS varied from 15.1 to $76.9 \%$ during the wheat growing 
season, which was generally lower than that in the peanut growing season due to soil evaporation and less precipitation.

The application of $\mathrm{N}$ fertiliser was found to significantly increase the soil concentration of $\mathrm{NH}+4-\mathrm{N}$ and NO- 3-N compared with the control; these concentrations sharply increased after fertilisation in all treatments, especially in the $0-20$ and $20-40 \mathrm{~cm}$ soil layers (Fig. 3). During the wheat growing season, peak soil NH+ 4-N and NO-3-N concentrations were observed after the jointing fertilisation, the peak values in JCF100 was higher than that in JCF70 and JCRF70. Thereafter, the soil $\mathrm{NH}+4-\mathrm{N}$ content rapidly decreased and remained low until the harvest period of wheat, while the soil NO- 3-N content of JCF100 reached another relatively large peak in the $0-20 \mathrm{~cm}$ soil layers in the filling stage of wheat. During the peanut growing season, soil concentrations of $\mathrm{NH}+4-\mathrm{N}$ and $\mathrm{NO}-3-\mathrm{N}$ were significantly higher in treatments JCF70 and JCRF70 compared to treatment JCF100 due to the fact that $30 \%$ of the total fertiliser was applied in the initial peanut flowering stage. Under the same fertiliser rate, the peaks of the soil NH+ 4-N and NO- 3-N concentrations were larger in treatment JCF70 than in treatment JCRF70. However, in treatment JCF70, the soil NH+ 4-N and NO- 3-N concentrations were mostly lower compared to those in treatment JCRF70, especially in the late peanut growth stage. The annual average soil $\mathrm{NH}+4-$ $\mathrm{N}$ contents were 15.0, 21.5, 22.9, and $24.8 \mathrm{mg} \mathrm{N} \mathrm{kg}^{-1}$ for CK, JCF100, JCF70, and JCRF70, respectively, and the annual average soil NO- 3-N contents were 5.4, 23.2, 25.3, and $27.4 \mathrm{mg} \mathrm{N} \mathrm{kg}^{-1}$ for CK, JCF100, JCF70, and JCRF70, respectively. Overall, the soil concentrations of $\mathrm{NH}+4-\mathrm{N}$ were lower than the NO- 3-N concentrations in all fertiliser treatments, except in the early wheat growing season in the $40-60 \mathrm{~cm}$ soil layer. Additionally, the concentration of soil NO- 3-N peaked not only after fertilisation but also after the rainfall events, and small peaks were observed on 07 June 2019.

\section{2. $\mathrm{CO}_{2}$ emission}

In the wheat growing season, except for a small peak which occurred after basal fertilisation during 20172018 , the $\mathrm{CO}_{2}$ emission fluxes remained at a low level in the overwintering period in all treatments (Fig. $4 \mathrm{~A}, \mathrm{~B})$. However, the $\mathrm{CO}_{2}$ emission fluxes resumed and reached their maximum two and three days after the jointing fertilisation and irrigation events. For the $\mathrm{CK}$, the $\mathrm{CO}_{2}$ emission fluxes was maintained at a low level until the harvest period of wheat, the application $\mathrm{N}$ fertiliser can significantly increase the flux of $\mathrm{CO}_{2}$ emission, and this change increased with increasing $\mathrm{N}$ application rate, the $\mathrm{CO}_{2}$ emission fluxes were higher by 16.3-71.9\% compared with CK over the two years (Fig. 4A-1,B-1). The largest $\mathrm{CO}_{2}$ emission flux occurred in treatment JCF100 (average $1495 \mathrm{mg} \mathrm{m}^{-2} \mathrm{~h}^{-1}$ ), followed by JCF70 (1285 mg m${ }^{-2} \mathrm{~h}^{-1}$ ), JCRF70 (1014 $\left.\mathrm{mg} \mathrm{m}^{-2} \mathrm{~h}^{-1}\right)$, and CK $\left(868 \mathrm{mg} \mathrm{m}^{-2} \mathrm{~h}^{-1}\right)$.

In the peanut growing season, the $\mathrm{CO}_{2}$ emission fluxes reached their maximum two days after the the second application of $\mathrm{N}$ fertiliser at the anthesis stage in 2018 , while it reached their maximum approximately 4 to 5 days in 2019, with the largest flux being observed in treatment JCF70 (average 1509 mg m $\left.{ }^{-2} \mathrm{~h}^{-1}\right)$, followed by JCRF70 (1253 $\left.\mathrm{mg} \mathrm{m}^{-2} \mathrm{~h}^{-1}\right)$, JCF100 (852 $\left.\mathrm{mg} \mathrm{m}^{-2} \mathrm{~h}^{-1}\right)$, and CK $\left(527 \mathrm{mg} \mathrm{m}^{-2} \mathrm{~h}^{-1}\right)$. The peak $\mathrm{CO}_{2}$ emission fluxes of treatments JCF70 and JCRF70 were higher by $83.6 \%$ and $52.9 \%$, 
respectively, compared with that of JCF100 (Fig. 4A-2,B-2). Due to a series of precipitation events (totalling approximately $86 \mathrm{~mm}$ ) which occurred between 27 July and 02 August 2019 (Fig. 1B), an obvious and large peak in $\mathrm{CO}_{2}$ emissions was observed on 02 August. In addition, the $\mathrm{CO}_{2}$ emission fluxes during the peanut growing season were higher than during the wheat growing season, especially in August and September from 2018-2019. At the same fertiliser rate, the $\mathrm{CO}_{2}$ fluxes were lower in treatment JCRF70 than in treatment JCF70 for both the wheat and peanut growing seasons over the two years.

The application of $\mathrm{N}$ fertiliser was found to significantly increase the cumulative $\mathrm{CO}_{2}$ emissions compared with $\mathrm{CK}$; with $\mathrm{N}$ fertilisation, the cumulative $\mathrm{CO}_{2}$ emissions were between 8648 and $16609 \mathrm{~kg}$ $\mathrm{CO}_{2}$ ha $^{-1}$ in 2018 and 10918 and $16870 \mathrm{~kg} \mathrm{CO}_{2}$ ha $^{-1}$ in 2019 during the wheat growing season, while those during the peanut growing season were between 9206 and $16940 \mathrm{~kg} \mathrm{CO}_{2} \mathrm{ha}^{-1}$ in 2018 and 16494 and $27700 \mathrm{~kg} \mathrm{CO}_{2} \mathrm{ha}^{-1}$ in 2019 (Table 2). Furthermore, split applications of $\mathrm{N}$ were found to significantly increase the cumulative $\mathrm{CO}_{2}$ emissions. The annual cumulative $\mathrm{CO}_{2}$ emission in treatment JCF70 was 9.0\% higher than that in treatment JCF100 over the two years. However, under the same fertiliser rate, the annual cumulative $\mathrm{CO}_{2}$ emission in treatment JCRF70 was lower by $14.1 \%$ compared with that of treatment JCF70. The annual accumulated $\mathrm{CO}_{2}$ emissions were significantly influenced by the fertilizer treatment and year, but not significantly affected by the interaction between the fertilizer treatment and the year (Table 3). Moreover, the results of the correlation analysis (Table 4) showed that the daily $\mathrm{CO}_{2}$ emission was significantly positively correlated with the soil temperature, the WFPS, and the soil NH+4-N concentration, with correlation coefficients of $0.43,0.55$, and 0.64 , respectively, at the $P<0.01$ level.

Table 2 Global warming potential (GWP) and global warming potential intensity (GHGI) under different nitrogen treatments. 


\begin{tabular}{|c|c|c|c|c|c|c|c|c|c|c|}
\hline \multirow[t]{3}{*}{ Year } & \multirow[t]{3}{*}{ Treatment } & \multicolumn{2}{|l|}{ Wheat } & \multicolumn{3}{|l|}{ Peanut } & \multicolumn{3}{|c|}{ Annual } & \multirow[b]{2}{*}{ GHGI } \\
\hline & & $\mathrm{CO}_{2}$ & $\mathrm{~N}_{2} \mathrm{O}$ & $\mathrm{CO}_{2}$ & $\mathrm{~N}_{2} \mathrm{O}$ & $\mathrm{CO}_{2}$ & $\mathrm{~N}_{2} \mathrm{O}$ & Yield & GWP & \\
\hline & & \multicolumn{2}{|c|}{$\left(\mathrm{kg} \mathrm{ha}^{-1}\right)$} & \multicolumn{2}{|l|}{$\left(\mathrm{kg} \mathrm{ha}^{-1}\right)$} & \multicolumn{3}{|c|}{$\left(\mathrm{kg} \mathrm{ha}^{-1}\right)$} & $\begin{array}{l}(\mathrm{kg} \\
\mathrm{CO}_{2^{-}} \\
\text {eq ha- } \\
\left.{ }^{1}\right)\end{array}$ & $\left(\mathrm{kg}^{-1}\right)$ \\
\hline \multirow[t]{4}{*}{$\begin{array}{l}2017- \\
2018\end{array}$} & CK & $\begin{array}{l}8648 \\
c\end{array}$ & $\begin{array}{l}1.12 \\
c\end{array}$ & $\begin{array}{l}9206 \\
c\end{array}$ & $\begin{array}{l}1.46 \\
d\end{array}$ & $\begin{array}{l}17854 \\
d\end{array}$ & $\begin{array}{l}2.38 \\
d\end{array}$ & $\begin{array}{l}10200 \\
d\end{array}$ & $\begin{array}{l}18624 \\
d\end{array}$ & $\begin{array}{l}1.83 \\
c\end{array}$ \\
\hline & JCF100 & $\begin{array}{l}12035 \\
b\end{array}$ & $\begin{array}{l}1.71 \\
b\end{array}$ & $\begin{array}{l}16940 \\
a\end{array}$ & $\begin{array}{l}2.55 \\
b\end{array}$ & $\begin{array}{l}28976 \\
\text { b }\end{array}$ & $\begin{array}{l}4.26 \\
c\end{array}$ & $\begin{array}{l}13257 \\
\mathrm{C}\end{array}$ & $\begin{array}{l}30243 \\
\text { b }\end{array}$ & $\begin{array}{l}2.81 \\
a\end{array}$ \\
\hline & JCRF70 & $\begin{array}{l}13176 \\
b\end{array}$ & $\begin{array}{l}1.82 \\
a\end{array}$ & $\begin{array}{l}12197 \\
b\end{array}$ & $\begin{array}{l}2.60 \\
c\end{array}$ & $\begin{array}{l}25373 \\
\mathrm{C}\end{array}$ & $\begin{array}{l}4.42 \\
b\end{array}$ & $\begin{array}{l}14627 \\
b\end{array}$ & $\begin{array}{l}26689 \\
\mathrm{C}\end{array}$ & $\begin{array}{l}1.82 \\
c\end{array}$ \\
\hline & JCF70 & $\begin{array}{l}16609 \\
a\end{array}$ & $\begin{array}{l}2.77 \\
a\end{array}$ & $\begin{array}{l}16094 \\
a\end{array}$ & $\begin{array}{l}2.80 \\
a\end{array}$ & $\begin{array}{l}32704 \\
a\end{array}$ & $\begin{array}{l}5.56 \\
\text { a }\end{array}$ & $\begin{array}{l}15490 \\
\text { a }\end{array}$ & $\begin{array}{l}34361 \\
\mathrm{a}\end{array}$ & $\begin{array}{l}2.22 \\
b\end{array}$ \\
\hline \multirow[t]{4}{*}{$\begin{array}{l}2018- \\
2019\end{array}$} & CK & $\begin{array}{l}10918 \\
d\end{array}$ & $\begin{array}{l}1.31 \\
d\end{array}$ & $\begin{array}{l}16491 \\
\mathrm{C}\end{array}$ & $\begin{array}{l}1.28 \\
d\end{array}$ & $\begin{array}{l}27409 \\
\mathrm{C}\end{array}$ & $\begin{array}{l}2.59 \\
d\end{array}$ & $\begin{array}{l}12464 \\
d\end{array}$ & $\begin{array}{l}28180 \\
C\end{array}$ & $\begin{array}{l}2.26 \\
c\end{array}$ \\
\hline & JCF100 & $\begin{array}{l}16870 \\
a\end{array}$ & $\begin{array}{l}2.33 \\
b\end{array}$ & $\begin{array}{l}24573 \\
b\end{array}$ & $\begin{array}{l}1.88 \\
c\end{array}$ & $\begin{array}{l}41443 \\
b\end{array}$ & $\begin{array}{l}4.21 \\
c\end{array}$ & $\begin{array}{l}15879 \\
C\end{array}$ & $\begin{array}{l}42698 \\
b\end{array}$ & $\begin{array}{l}2.69 \\
a\end{array}$ \\
\hline & JCRF70 & $\begin{array}{l}14872 \\
\mathrm{C}\end{array}$ & $\begin{array}{l}1.66 \\
c\end{array}$ & $\begin{array}{l}26140 \\
a\end{array}$ & $\begin{array}{l}2.89 \\
b\end{array}$ & $\begin{array}{l}41013 \\
b\end{array}$ & $\begin{array}{l}4.55 \\
b\end{array}$ & $\begin{array}{l}19134 \\
\text { a }\end{array}$ & $\begin{array}{l}42368 \\
\text { b }\end{array}$ & $\begin{array}{l}2.19 \\
\mathrm{C}\end{array}$ \\
\hline & JCF70 & $\begin{array}{l}15880 \\
b\end{array}$ & $\begin{array}{l}2.52 \\
a\end{array}$ & $\begin{array}{l}27700 \\
a\end{array}$ & $\begin{array}{l}3.32 \\
a\end{array}$ & $\begin{array}{l}43581 \\
a\end{array}$ & $\begin{array}{l}5.84 \\
a\end{array}$ & $\begin{array}{l}18618 \\
b\end{array}$ & $\begin{array}{l}45321 \\
a\end{array}$ & $\begin{array}{l}2.47 \\
b\end{array}$ \\
\hline
\end{tabular}

Different letters within a column represent significantly different mean values at $\mathrm{P}<0.05$, according to the LSD test.

Table 3 ANOVA for the effects of $\mathrm{N}$ treatment and year $(\mathrm{Y})$ on annual $\mathrm{CO}_{2}$ and $\mathrm{N} 2 \mathrm{O}$ emissions, and total grain yields.

\begin{tabular}{|c|c|c|c|c|c|c|c|c|c|}
\hline \multirow[t]{2}{*}{ Factors } & \multicolumn{3}{|c|}{ Cumulative CO2 (kg ha-1) } & \multicolumn{3}{|c|}{ Cumulative N2O (kg ha-1) } & \multicolumn{3}{|c|}{ Yield (kg ha-1) } \\
\hline & F value & df & $\mathrm{p}$ & F value & $\mathrm{df}$ & $\mathrm{p}$ & $\mathrm{F}$ value & df & $\mathrm{p}$ \\
\hline Year & 558.008 & 1 & $\varangle 0.001$ & 0.6410 & 1 & 0.4351 & 37.186 & 1 & $\nabla 0.001$ \\
\hline $\mathrm{N}$ treatment & 172.898 & 3 & $₫ 0.001$ & 129.5880 & 3 & $\varangle 0.001$ & 27.058 & 3 & $\nabla 0.001$ \\
\hline$N \times Y$ & 6.5160 & 3 & 0.4542 & 0.4310 & 3 & 0.7335 & 0.9180 & 3 & 0.0004 \\
\hline
\end{tabular}

Table 4 Correlations between greenhouse-gas emissions and environmental factors 


\begin{tabular}{|lll|}
\hline Correlations & $\mathrm{CO}_{2}$ & $\mathrm{~N}_{2} \mathrm{O}$ \\
\hline Soil temperature & $0.43^{\star \star}$ & $-0.40 \star *$ \\
\hline WFPS & $0.55^{\star \star}$ & 0.15 \\
\hline $\mathrm{NH}+4-\mathrm{N}$ & $0.64^{\star \star}$ & -0.13 \\
\hline $\mathrm{NO}-3-\mathrm{N}$ & $0.45^{\star}$ & -0.05 \\
\hline
\end{tabular}

$*$ significant at $\mathrm{P}<0.05 ; * *$ significant at $\mathrm{P}<0.01$

\section{3. $\mathrm{N}_{2} \mathrm{O}$ emission}

The $\mathrm{N}_{2} \mathrm{O}$ emission fluxes exhibited the same trends as the $\mathrm{CO}_{2}$ emission fluxes for both the wheat growing season and the peanut growing season in the two years(Fig. $5 A, B)$. The application of $N$ fertiliser was found to significantly increase the $\mathrm{N}_{2} \mathrm{O}$ emission fluxes relative to $\mathrm{CK}$, especially after irrigation and precipitation. In the $\mathrm{N}$ fertilisation treatments, the average $\mathrm{N}_{2} \mathrm{O}$ emission fluxes ranged from 13.8 to 243.3 $\mu \mathrm{g} \mathrm{m}^{-2} \mathrm{~h}^{-1}$ in 2018 and from 13.6 to $260.5 \mathrm{~g} \mathrm{~m} \mathrm{~m}^{-2} \mathrm{~h}^{-1}$ in 2019 during the wheat growing season, while those during the peanut growing season ranged from 26.5 to $143.3 \mu_{g^{-2} ~ m^{-1}}$ in 2018 and from 24.3 to $130.9 \mathrm{\mu g} \mathrm{m}^{-2} \mathrm{~h}^{-1}$ in 2019. The $\mathrm{N}_{2} \mathrm{O}$ emission fluxes reached a first peak on the second day after jointing fertilisation and irrigation for all treatments in the two years. The average value of this peak was $260.5 \mu \mathrm{g}$ $\mathrm{m}^{-2} \mathrm{~h}^{-1}$ under treatment JCF100, which was significantly higher than the values obtained for treatments JCF70 and JCRF70. After which $\mathrm{N}_{2} \mathrm{O}$ emission sharply decreased except a relatively large peak was seen on 19 May in 2019 due to the irrigation event. During the peanut growing season, the peak in $\mathrm{N}_{2} \mathrm{O}$ emissions after anthesis fertilisation was lower than that after jointing fertilisation due to the lack of irrigation in this fertilisation event, but emission valus were maintained at a relative high level until the harvest period of peanut. The $\mathrm{N}_{2} \mathrm{O}$ emission fluxes reached the peak on the second day for treatments JCF70 and JCRF70 after anthesis fertilisation, and the $\mathrm{N}_{2} \mathrm{O}$ emission flux for JCF70 was higher than for JCRF70 all the time from day two to day six (Fig. 5A-2,B-2). In all the $N$ fertilisation treatments, the mean $\mathrm{N}_{2} \mathrm{O}$ emission flux was higher in the growing season of peanut than in the growing season of wheat due to the higher temperature and greater amount of rainfall in the former in both years(Fig. 1A,B). The second peak of $\mathrm{N}_{2} \mathrm{O}$ emissions was $70.6 \%$ and $49.5 \%$ higher in JCR70 and JCRF70, respectively, compared to that in the JCF100 treatment (Fig. 5 a-2,B-2). Due to an irrigation event on 18 May 2019, peaks of $\mathrm{N}_{2} \mathrm{O}$ emission fluxes occurred on 19 May 2019 for all treatments (Fig. 5A).

In both years, splitting $\mathrm{N}$ application into three applications was shown to significantly increase the cumulative $\mathrm{N}_{2} \mathrm{O}$ emissions compared with two $\mathrm{N}$ applications, while no significant difference was found during the wheat growing season. Across the two seasons, the average total cumulative $\mathrm{N}_{2} \mathrm{O}$ emissions in CK, JCF100, JCF70, and JCRF70 were 2.49, 4.24, 5.70, and $4.49 \mathrm{~kg} \mathrm{~N}_{2} \mathrm{O} \mathrm{ha}{ }^{-1}$, respectively (Table 2). The emission fluxes of $\mathrm{N}_{2} \mathrm{O}$ in treatment JCRF70 were generally lower than those in treatment JCF70 (Fig. 
$5 \mathrm{~A}, \mathrm{~B})$ and the annual cumulative $\mathrm{N}_{2} \mathrm{O}$ emissions in treatment JCRF70 were lower by $34.3 \%$ in 2018 and by $51.8 \%$ in 2019 during the wheat growing season, and those lower by $7.9 \%$ and $13.0 \%$ during the peanut growing season, respectively, compared with treatment JCF70. The annual accumulated $\mathrm{N}_{2} \mathrm{O}$ emissions were significantly influenced by the fertilizer treatment, but not significantly affected by the year and the interaction between the fertilizer treatment and the year (Table 3). Additionally, in all treatments, soil variables were found to have no significant correlation with daily $\mathrm{N}_{2} \mathrm{O}$ emission fluxes, while there was found to be a negative correlation between $\mathrm{N}_{2} \mathrm{O}$ flux and soil temperature (Table 4).

\subsection{Grain yields and GHGI}

Compared to CK, wheat grain yields were found to be significantly higher by $36.7-54.3 \%$ in 2018 and by 31.8-57.6\% in 2019 under all $\mathrm{N}$ fertiliser treatments (Fig. 6 A, B). Meanwhile, the wheat grain yield of treatment JCF70 was higher than that of treatment JCF100 despite the fertiliser use being a $30 \%$ lower. Compared with treatment JCF100, the grain yields in treatments JCF70 and JCRF70 were higher by $10.9 \%$ and $12.8 \%$, respectively, in 2018 , and by $16.7 \%$ and $19.6 \%$, respectively, in 2019 . However, no significant difference in grain yield was found between treatments JCF70 and JCRF70. Split N fertiliser application was found to significantly increase the pod yield and kernel yield of peanut in both growing seasons compared with CK (Fig. 6 C, D). Compared with treatment JCF100, the pod yields in treatments JCF70 and JCRF70 were higher by $9.7-21.0 \%$ in 2018 and by $14.6-24.8 \%$ in 2019 , respectively.

Additionally, under the same $\mathrm{N}$ fertiliser rate, the pod yields for treatment JCRF70 in 2018 and 2019 were $5.2 \%$ and $8.9 \%$ higher than for treatment JCF70, respectively.

As shown in Table 2, N application was found to significantly increase GWP and GHGI in both the wheat and peanut growing seasons. During the wheat growing season, the GWP and GHGI in JCF100 were higher than that in treatments JCF70 and JCRF70 due to all the fertiliser were applied to wheat. However, there were no statistically significant difference of GWP between treatments JCF100 and JCRF70 for the peanut growing seasons and the annual. In addition, the annual lowest GHGI was obtained in treatment JCRF70 due to a higher total grain yield in both years. In comparison with the respective urea treatments, CRF treatments were found to significantly decrease GHGI in both the wheat and peanut growing seasons.

\section{Discussion}

\subsection{Effects of splitting $\mathbf{N}$ applications on $\mathrm{GHG}$ emissions}

For a given total $\mathrm{N}$ rate, when the rate of $\mathrm{N}$ fertiliser application is kept low through split application, lower cumulative $\mathrm{CO}_{2}$ emissions would be expected compared with a single application. However, in the present study, throughout the trial period, three splits of $\mathrm{N}$ application were found to significantly increase the $\mathrm{CO}_{2}$ emissions, and the high and short-term $\mathrm{CO}_{2}$ emission peaks were recorded following fertilisation. This finding is consistent with most previous studies (Ward et al., 2017; Wang et al., 2016). The annual cumulative $\mathrm{CO}_{2}$ emissions in treatment JCF70 were shown to be $5.2 \%$ higher than those in treatment 
JCF100. This is mainly due to the third top-dressed fertiliser at the anthesis stage of peanut, which may indirectly affect the respiration of microorganisms in crops and soil and directly affect soil C content, while $\mathrm{CO}_{2}$ emissions are comprised of soil respiration and plant respiration, and the $\mathrm{CO}_{2}$ fluxes increase with the soil organic C content (Ward et al., 2017). Except for the third top-dressed fertiliser, the higher temperature and WFPS in the peanut growing season exacerbate this process. Zou et al. (2018) and Rustad et al. (2001) also observed increases in soil $\mathrm{CO}_{2}$ emissions following warming and precipitation in numerous regions. As we know, that nitrogen availability can be utilized by soil respiration and fertiliser as major factors affecting soil respiration in farmland, directly by influencing root and microbial activities and indirectly by influencing physical and chemical soil properties (Ding et al., 2007; Huang et al., 2012; Fan et al., 2015; Gong et al., 2015). Therefore, it can be reasonably assumed that $\mathrm{N}$ fertilisation may impact $\mathrm{CO}_{2}$ emissions by affecting these factors. Additionally, compared to the fertiliser treatments, $\mathrm{CK}$ had a smaller $\mathrm{CO}_{2}$ emission peak at the jointing stage of wheat, the most likely reason for which is that the field was irrigated after jointing fertilisation. In the NCP, farmers generally irrigate after fertilisation, thereby maintaining the soil moisture in the growing season, while the soil WFPS can significantly affect $\mathrm{CO}_{2}$ emissions (Dossou-Yovo et al., 2016). These results illustrate that the $\mathrm{CO}_{2}$ emissions peak accompanies irrigation, and fertilisation could improve the peak of $\mathrm{CO}_{2}$ emissions.

As shown in Table 4, a significant positive correlation was observed between soil temperature and cumulative $\mathrm{CO}_{2}$ emissions. $\mathrm{CO}_{2}$ emission peaks in the wheat growing season were found to be higher than those in the peanut growing season. Besides a high fertilisation rate, this can be attributed to the fact that the field was irrigated after jointing fertilisation. However, the cumulative emissions of $\mathrm{CO}_{2}$ in the peanut growing season were significantly larger than those in the growing season of wheat for all treatments. This apparent contradiction has three possible explanations. First, in the NCP, the highest air temperature usually occurs between June and August. The higher soil temperature in the peanut growing season leads to enhanced respiration of peanut plants and soil microbes. Second, the anthesis stage is the key period for the rapid growth of peanut plants. The third fertilisation greatly promotes root growth and the accumulation of aboveground biomass, which leads to the increase of carbon inputs to the soil and the induction of enzyme activity, which may induce the mineralisation of soil organic matter (Du et al., 2018b; Lu et al., 2011). Third, previous studies showed that $\mathrm{CO}_{2}$ emissions from soil are caused by autotrophic and heterotrophic respiration, which can be affected by WFPS (Buragienè et al., 2019). In our study, a significant positive correlation was found between soil temperature and WFPS when several strong precipitation events occurred from late July to early August (Fig. 1A,B), during which the WFPS remained at a high level for several consecutive days (Fig. 1C). The findings of Wang et al. (2013) were comparable; they reported high $\mathrm{CO}_{2}$ concentrations in the warm and moist maize growing season and low concentrations in the winter-wheat growing season in a winter-wheat-summer-maize double-crop rotation.

Agricultural production is a primary source of atmospheric $\mathrm{N}_{2} \mathrm{O}$ and contributes around $60 \%$ to human $\mathrm{N}_{2} \mathrm{O}$ emissions (Reay et al. 2012), mainly due to the input of excessive $\mathrm{N}$ fertiliser. In wheat-peanut relay intercropping systems, the typical farmer's practice is to apply all fertiliser to the wheat, and this kind of 
centralized application of fertiliser will immediately increase the soil NO- 3-N contents to a level that is far beyond the range of wheat absorption and utilization at this stage. Therefore, the excessive soil NO- 3-N will produce $\mathrm{N}_{2} \mathrm{O}$ through nitrification via the oxidation of ammonia $\left(\mathrm{NH}_{3}\right)$ to nitrite $(\mathrm{NO}-2-\mathrm{N}) . \mathrm{N}_{2} \mathrm{O}$ can also be produced via denitrification. Many researchers have studied the impact of split $\mathrm{N}$ application on $\mathrm{N}_{2} \mathrm{O}$ emission fluxes; however, no consensus has been reached on this issue. Cumulative nitrous oxide emissions in the growing season following urea application in three split applications were found to be significantly higher compared to a one-time application in the corn stage of a corn-soybean rotation (Venterea and Coulter 2015) and in maize cultivation in a semiarid region in Central China (Wang et al., 2016). Additionally, Yan et al. (2001) observed no significant effect on $\mathrm{N}_{2} \mathrm{O}$ emissions when using split $\mathrm{N}$ application in maize cultivation under low precipitation, however proposed that a significant reduction in $\mathrm{N}_{2} \mathrm{O}$ emissions would be expected from split $\mathrm{N}$ application under normal rainfall conditions. Conversely, Burton et al. (2008) showed that the split application of $\mathrm{N}$ reduced $\mathrm{N}_{2} \mathrm{O}$ emissions in years with heavy rainfall between planting and hilling.

In this study, the $\mathrm{N}_{2} \mathrm{O}$ emissions in fertiliser treatment JCF70 were found to be $38.7 \%$ higher than those in treatment JCF100 across all studied years and rotations. Comparable findings were also reported by Wang et al. (2016), who reported that, in semiarid farmland, $\mathrm{N}$ application with three splits tended to increase $\mathrm{N}_{2} \mathrm{O}$ emissions as a result of the strong and frequent rainfall in the middle and late maize growth periods. Furthermore, Liu et al. (2011) and Scheer et al. (2012) found that irrigation and rainfall had an important influence on the cumulative soil $\mathrm{N}_{2} \mathrm{O}$ emissions, especially when combined with $\mathrm{N}$ fertilisation. This is consistent with the findings of the present study. A higher $\mathrm{N}_{2} \mathrm{O}$ emission peak was observed on 04 April after fertilisation closely followed by irrigation events compared to the $\mathrm{N}_{2} \mathrm{O}$ emission peak on 27 June which only had irrigation, not rain (Fig. 4A). This can mainly be attributed to the fact that soil concentrations of $\mathrm{NH}+4-\mathrm{N}$ and NO-3-N increased following irrigation and fertilisation (Fig. 3), which provided an adequate substrate for nitrification and denitrification. This led to rapid rates of hydrolysis and nitrification during the $\mathrm{N}$ fertilisation (Liu et al., 2003) and thus an extremely large quantity of $\mathrm{N}_{2} \mathrm{O}$ was immediately emitted, leading to an emissions peak. In the present study, we observed a positive correlation between emissions of $\mathrm{N}_{2} \mathrm{O}$ and soil temperature in the wheat growing season and a negative correlation in the peanut growing season, which is close to the results of a past study (Wang et al., 2016). However, other research found a significant positive correlation between $\mathrm{N}_{2} \mathrm{O}$ emissions and soil temperature (Ding et al., 2007; Allen et al., 2010). The negative correlation that was observed in the present study between $\mathrm{N}_{2} \mathrm{O}$ emissions and soil temperature in the peanut growing season may be due to the high $\mathrm{N}_{2} \mathrm{O}$ emissions immediately after precipitation, when soil temperature is low (Fig. 1C). This demonstrates the specificity of the impact of soil temperature on GHG emissions under diverse environmental conditions and agricultural management styles.

\subsection{Effects of CRF on GHG emissions}

In general, many synthetic $\mathrm{N}$ fertilisers are available to agricultural managers. Previous research has concentrated on the impact of various kinds of chemical $\mathrm{N}$ fertiliser on $\mathrm{CO}_{2}$ emissions from soil. These 
studies found that $\mathrm{N}$ fertiliser application results in temporary increases in $\mathrm{CO}_{2}$ concentrations and that soil respiration differs significantly between different forms of $\mathrm{N}$ fertiliser. Chi et al. (2020) reported that, during the entire sampling season in wheat-maize rotations, the contents of soil $\mathrm{N}$ and $\mathrm{C}$ under slowrelease fertilisation was able to effectively control the $\mathrm{CO}_{2}$ emission flux. In the present study, the cumulative $\mathrm{CO}_{2}$ emissions of treatment JCF70 were found to be significantly higher than those of treatment JCRF70. This may be due to the fact that the rapid release of nutrients in the CCF treatment resulted in the increase of soil $\mathrm{N}$ content, thus increasing the $\mathrm{CO}_{2}$ emissions. Additionally, the cumulative $\mathrm{CO}_{2}$ emissions of treatment JCRF70 were found to be significantly lower than those of treatment JCF70, and as shown in Table 2, there was no significant difference in $\mathrm{CO}_{2}$ emissions between treatments JCF70 and JCF100. These findings indicate that the use of CRF could reduce cumulative $\mathrm{CO}_{2}$ emissions from split $\mathrm{N}$ application. Previous studies found that nitrogen availability can be utilised by soil respiration and that there exists a process between the application of nitrogen and soil $\mathrm{CO}_{2}$ emission. During such a process, the available $\mathrm{N}$ is slowly released from the CRF during decomposition. This $\mathrm{N}$ release is controlled by a polymer membrane (Liang and Liu, 2006). This suggests that CRF could reduce $\mathrm{CO}_{2}$ emissions by the controlled release of nitrogen.

In our research, the effects of fertiliser management and year on cumulative $\mathrm{CO}_{2}$ emissions were highly significant $(P<0.001)$, however, no significant fertiliser managementxyear interaction effects were observed on cumulative $\mathrm{CO}_{2}$ emissions (Table 3). Additionally, as shown in Table 2, during the wheat growing season, cumulative $\mathrm{CO}_{2}$ emissions were significantly lower in treatment JCRF70 than treatment JCF70, however, there was no significant difference during the peanut growing season from 2018-2019. This shows that the means by which fertiliser affects $\mathrm{CO}_{2}$ emissions is complex, the influences of other factors on $\mathrm{CO}_{2}$ emissions, such as temperature, WFPS, soil texture, $\mathrm{NH}+4-\mathrm{N}$ and NO-3-N. Similar findings were made by Buragienè et al. (2019) and Ward et al. (2017).

The intensity of nitrification and denitrification are functions of soil concentrations of $\mathrm{NH}+4-\mathrm{N}$ and NO- 3$\mathrm{N}$, respectively (Smith et al., 1998a, b; Dobbie and Smith 2003). Previous studies have shown that there is a positive correlation between nitrification and denitrification and the soil mineral $\mathrm{N}$ content in cool and humid regions only when this concentration is greater than $5 \mathrm{mg} \mathrm{N} \mathrm{kg}^{-1}$ (Chantigny et al., 1998). Under the same fertiliser rate, the use of CRF has been identified as a possible mitigation strategy by the IPCC as it can regulate the timing of $\mathrm{N}$ release by diffusion through the fertiliser's coating, which better synchronises with the crop's demand for fertiliser $\mathrm{N}$ and thereby reduces soil NO- 3-N accumulation after fertiliser application, at least temporarily, and thus decreases the quantity of $\mathrm{N}$ that is available for denitrification (Shaviv et al., 2001; Ji et al., 2013). In our study, both CRF and CCF were found to increase the peak $\mathrm{N}_{2} \mathrm{O}$ emissions from soil, however the former led to a smaller increase than the latter. Compared with treatment JCF70, the cumulative $\mathrm{N}_{2} \mathrm{O}$ emissions in treatment JCRF70 were lower by $34.1 \%$ and $13.0 \%$ in the wheat and peanut growing seasons, respectively. This was due to the lower concentrations of $\mathrm{NH}+4-\mathrm{N}$ and NO- 3-N in the CRF treatment compared with the CCF treatment. Our study found no correlation between soil concentrations of $\mathrm{NH}+4-\mathrm{N}$ or NO- 3-N and $\mathrm{N}_{2} \mathrm{O}$ emissions (Table 4). Similarly, 
Zhong et al. (2016) and Ji et al. (2013) did not observe a correlation between these parameters, despite the fact that most studies observed that $\mathrm{N}_{2} \mathrm{O}$ emissions are strongly correlated with soil concentrations of $\mathrm{NH}+4-\mathrm{N}$ or NO- 3-N (Wang et al., 2016; Shi et al., 2013). These studies stated that $\mathrm{N}$ fertilisers provide $\mathrm{N}$ resources for $\mathrm{N}_{2} \mathrm{O}$ production, while other environmental characteristics such as soil water content and soil temperature determine $\mathrm{N}_{2} \mathrm{O}$ production (Schuster and Conrad 1992). In the future, it is important to investigate the link between $\mathrm{N}_{2} \mathrm{O}$ emissions and soil concentrations of $\mathrm{NH}+4-\mathrm{N}$ or NO- 3-N under a variety of soil moisture regimes. In this study, we found that in most cases, the soil NO- 3-N concentration was lower in the CRF treatment than in the CCF treatment. Nevertheless, at the end of the peanut harvest stage, higher soil concentrations of $\mathrm{NH}+4-\mathrm{N}$ and NO-3-N were observed in the CRF treatment compared to the CCF treatment which supports the results of previous research (Ji et al., 2013; Peng et al., 2011). This proves that CRF released fertiliser $\mathrm{N}$ slowly, thus extending nitrogen supply, and released some $\mathrm{N}$ in the late peanut growth stage.

\subsection{Yield, GWP, and GHGI}

Our study found that split $\mathrm{N}$ application not only significantly increased the peanut pod yield but also increased the wheat grain yield, despite a $30 \%$ reduction in fertiliser use for wheat (Fig. 6A). This result can be explained by the findings of our previous study, in which the application of $\mathrm{N}$ fertiliser with three splits was shown to increase the plant uptake of $\mathrm{N}$ derived from fertiliser and $\mathrm{N}$ harvest index $(\mathrm{NHI})$ and reduce $\mathrm{N}$ loss, thus increasing the total grain yield relative to a treatment where the total yearly $\mathrm{N}$ fertiliser was added to wheat in two splits (Liu et al., 2018). In wheat-peanut relay intercropping rotation systems, local farmers traditionally apply $100 \%$ of the fertiliser in the wheat growing season to ensure high wheat yield. The farmers' average $\mathrm{N}$ application rate for wheat is significantly higher than the recommended rate to satisfy grain yield and NUE (Ma et al., 2015; Li et al., 2011). Such inappropriate application methods not only decrease NUE but also lead to deficient soil fertility following the wheat harvest and result in insufficient soil nutrients for peanut growth in the middle and late growth stages, thus resulting in a low yield (Liu et al., 2019). In the present study, treatment JCF70 better matched soil nutrient availability with crop demand by the application of $\mathrm{N}$ with three splits. Furthermore, for a given proportion of $\mathrm{N}-\mathrm{P}_{2} \mathrm{O}_{5}-$ $\mathrm{K}_{2} \mathrm{O}$ and equal quantities of nutrients, no significant difference was observed in the wheat grain yield between treatments JCF70 and JCRF70. However, the peanut pod yield and the total yield of treatment JCRF70 were found to be significantly higher by $8.9 \%$ and $5.3 \%$ respectively, relative to treatment JCF70. Additionally, treatment JCRF70 was found to significantly reduce the GWP in both the wheat and peanut growing seasons compared to treatment JCF70. Therefore, the investigated CRF technologies can be expected to have positive effects on environmental quality and crop production in the long-run. Additionally, to prevent environmental pollution, maintain yield, and achieve economic benefits, the reduced application of CRF and the combined application of urea and CRF warrants further study.

The goal of agricultural production in a whole agro-ecosystem is to increase the economic output from crops and the sustainable development of agriculture while achieving a win-win situation in terms of the economic and environmental aspects of farmland ecosystems (Song et al., 2013). Therefore, good agronomic practices should lead to higher grain yield and lower GHG emissions. In the current study, the 
annual GWP of treatment JCF70 was found to be significantly higher than that of JCF100, while the GHGI of treatment JCF70 was not found to increase due to a higher grain yield. The same annual GWP was obtained for treatments JCF100 and JCRF70, however the lowest GHGI was observed for treatment JCRF70 due to it having the highest grain yield. Some previous studies also found that CRF could significantly reduce the $\mathrm{CO}_{2}$ and $\mathrm{N}_{2} \mathrm{O}$ emissions in wheat or rice cropping systems compared with urea (Chi et al., 2020; Ji et al., 2013). The findings of this study show that the slow release of fertiliser reduces GHG emissions and maintains a high yield.

Optimizing $\mathrm{N}$ fertiliser inputs in crop rotation systems may be an effective strategy for reducing GHG emissions. Liang et al. (2017) found that, in a double-season rice cropping system, the total grain yield increased by $6.7-13.9 \%$ and the GHG emissions significantly decreased when the $\mathrm{N}$ rate was reduced from 202.5 to $150 \mathrm{~kg} \mathrm{ha}^{-1}$. Shi et al. (2013) found that reducing the total $\mathrm{N}$ application rate in a typical winter wheat-summer maize rotation system led to no significant loss in yield and achieved economic and environmental benefits. Numerous studies have shown that over-fertilisation is a serious crisis in agroecosystems in China(Huang and Tang, 2010; Chen et al., 2017; Liang et al., 2017; Shi et al., 2013). In the present study, the GHG emissions decreased in the wheat growing season due to the reduced amount of fertiliser applied to wheat. Similarly, Ji et al. (2012) and Liu et al. (2015) reported that a $20 \%$ reduction in the optimal rates of $\mathrm{N}$ fertilisation and changes to the basal/topdressing ratio could increase yields and reduce GHG emissions. Our previous experimental study (Liu et al., 2018) also showed that treatment JCF70 is environmentally friendly in that it significantly decreased the $\mathrm{N}$ loss into the environment compared with treatment JCF100. However, we were not able to determine a clear relationship between fertilisation and $\mathrm{N}_{2} \mathrm{O}$ emissions due to the lack of different fertilization levels. The present study clearly showed that the CRF treatment could reduce the GHG emissions during the peanut growing seasons (Table 2). This is consistent with the findings of Chi et al. (2020) and Shi et al. (2013), who reported a decrease in $\mathrm{CO}_{2}$ and $\mathrm{N}_{2} \mathrm{O}$ emissions, respectively, in wheat-maize rotations. They found that reducing the $\mathrm{N}$ application rate and using controlled-release $\mathrm{N}$ fertiliser is a promising management practice to achieve the two objectives of sustaining grain yield and reducing GHG emissions in the NCP. Mainly because there is a rapid rate of hydrolysis and nitrification after applying $N$ fertiliser in the form of urea, especially for excessive $\mathrm{N}$ fertiliser applied in a single application, and almost all peanut and corn growth occurs from June to September, during which period the frequent precipitation and high temperature accelerate the denitrification process.

\section{Conclusion}

In wheat-peanut rotation systems, there is a prominent seasonal variation in soil GHG fluxes, and the cumulative GHG emissions are significantly affected by the fertilisation treatment, fertiliser type, and soil temperature. In this study, three splits of $\mathrm{N}$ application were found to significantly increase the total grain yields, however they also increased GHG emissions. Under the same fertiliser rate, in the CRF treatment, the GWP was significantly lower and the total grain yield was significantly higher compared to the CCF treatment. Thus, the CRF treatment was found to have lower GHG emissions than the CCF treatment. 
Therefore, to simultaneously maintain crop yield and reduce GHG emissions, three splits of $\mathrm{N}$ application and the use of CRF are recommended. Taking economic benefits into consideration, more study is necessary to elucidate the impacts of reducing the total application rate of CRF or the combined application of urea with CRF on crop yield and GHG emissions due to the high cost of CRF.

\section{Declarations}

Author contribution $X L$ and $Z L$ initiated and designed the research. ZL analyzed the data, and wrote the manuscript. $\mathrm{CZ}, \mathrm{HL}$ and $\mathrm{JZ}$ do the experiment, sample plant, $\mathrm{XL}$ revised and edited the manuscript.

Funding This work was funded by the National Key Research and Development Program of China (Grant No. 2018YFD1000900), the Shandong Key Research and Development Program (2018YFJH0601-3), the Major Agricultural Applied Technological Innovation Projects in Shandong Province (Grant No. SD2019ZZ11), and the Shandong Modern Agricultural Technology and Industry System. (Grant No. SDAIT-04-01).

Data availability The data used to support the findings of this study are available from the corresponding author upon request.

Ethics approval Not applicable.

Consent to participate Not applicable.

Consent for publication Not applicable.

Competing interests The authors declare no competing interests.

\section{References}

1. Akiyama $H$, Xiaoyuan $Y$, Kazuyuki $Y$ (2010) Evaluation of the effectiveness of enhanced-efficiency fertilizers as mitigation options for $\mathrm{N}_{2} \mathrm{O}$ and $\mathrm{NO}$ emissions from agricultural soils: meta-analysis. Global Change Biol 16:1837-1846. https://doi.org/10.1111/j.1365-2486.2009.02031.x

2. Allen DE, Kingston G, Rennenberg H, Dalal RC, Schmidt S (2010) Effect of nitrogen fertilizer management and waterlogging on nitrous oxide emission from subtropical sugarcane soils. Agr Ecosyst Environ 136:209-217. https://doi.org/10.1016/j.agee.2009.11.002

3. Ardell DH, Stephen JD, Francesco A (2010) Tillage and inorganic nitrogen source effects on nitrous oxide emissions from irrigated cropping systems. Soil Sci Soc Am J 74:436-445. https://doi.org/10.2136/sssaj2009.0072

4. Abalos D, Sanchez-Martin L, Garcia-Torres L, van Groenigen JW, Vallejo A (2014) Management of irrigation frequency and nitrogen fertilization to mitigate GHG and NO emissions from drip-fertigated crops. Sci Total Environ 490, 880-888. https:// doi.org/10.1016/j.scitotenv.2014.05.065 
5. Beare $\mathrm{MH}$, Gregorich EG, St-Georges $\mathrm{P}$ (2009) Compaction effects on $\mathrm{CO}_{2}$ and $\mathrm{N}_{2} \mathrm{O}$ production during drying and rewetting of soil. Soil Biol Biochem 41:611-621.

https://doi.org/10.1016/j.soilbio.2008.12.024

6. Burton DL, Zebarth BJ, Gillam KM, MacLeod JA (2008) Effect of split application of fertilizer nitrogen on $\mathrm{N}_{2} \mathrm{O}$ emissions from potatoes. Can J Soil Sci 88:229-239. https://doi.org/10.4141/CJSS06007

7. Ball BC, McTaggart IP, Scott A (2004) Mitigation of greenhouse gas emissions from soil under silage production by use of organic manures or slow-release fertilizer. Soil Use Manage 20:287-295. https://doi.org/10.1111/j.1475-2743.2004.tb00371.x

8. Buragienė S, Šarauskis E, Romaneckas K, Adamavičienè A, Kriaučiūnienė Z, Avižienytė D, Marozas V, Naujokienè $\mathrm{V}$ (2019) Relationship between $\mathrm{CO}_{2}$ emissions and soil properties of differently tilled soils. Sci Total Environ 662:786-795. https://doi.org/10.1016/j.scitotenv.2019.01.236

9. Below FE (2001) Nitrogen metabolism and crop productivity. In: Pessarakli M (ed) Handbook of Plant and Crop Physiology Second. Marcel Dekker, Inc., New York, pp 385-406

10. Chen GQ, Zhang B (2010) Greenhouse gas emissions in China 2007: inventory and inputeoutput analysis. Energy Pol 38:6180-6193. https://doi.org/10.1016/j.enpol.2010.06.004

11. Chi YB, Yang PL, Ren SM, Ma N, Yang J, Xu Y (2020) Effects of fertilizer types and water quality on carbon dioxide emissions from soil in wheat-maize rotations. Science of The Total Environment 698:134010. https://doi.org/10.1016/j.scitotenv.2019.134010

12. Chantigny MH, Prevost D, Angers DA, Simard RR, Chalifour FP (1998) Nitrous oxide production in soils cropped to corn with varying $\mathrm{N}$ fertilization. Can J Soil Sci 78:589-596. https://doi.org/10.4141/S98-009

13. Dossou-Yovo ER, Brüggemann N, Jesse N, Huat J, Ago EE, Agbossou EK (2016) Reducing soil $\mathrm{CO}_{2}$ emission and improving upland rice yield with no-tillage, straw mulch and nitrogen fertilization in northern Benin. Soil Tillage Res 156:44-53

14. Du YD, Niu WQ, Zhang Q, Cui BJ, Gu XB, Guo LL, Liang BH (2018) Effects of nitrogen on soil microbial abundance, enzyme activity, and nitrogen use efficiency in greenhouse celery under aerated irrigation. Soil Sci Soc Am J 82:606-613

15. Ding WX, Cai Y, Cai ZC, Yagi K, Zheng XH (2007) Nitrous oxide emissions from an intensively cultivated maize-wheat rotation soil in the North China Plain. Sci Total Environ 373:501-511. https://doi.org/10.1016/j.scitotenv.2006.12.026

16. Dobbie KE, Smith KA (2003) Nitrous oxide emission factors for agricultural soils in Great Britain: the impact of soil water filled pore space and other controlling variables. Global Change Biol 9:204-218. https://doi.org/10.1046/j.1365-2486.2003.00563.x

17. Elkan GH, Wynne JC, Schneeweis TJ, Isleib TG (1980) Nodulation and nitrogenase activity of peanuts inoculated with single strain isolates of rhizobium. Peanut Sci 7:95-97. https://doi.org/10.3146/i0095-3679-7-2-9 
18. Guo HH, Yang LP, Li XH, Yang P, Wan SB (2010) Characteristics of production and quality of peanut in Huang-Huai-Hai region. Chin J Eco Agric 18:1233-1238.

https://doi.org/10.3724/SP.J.1011.2010.01233

19. Guo JP, Zhou CD (2007) Greenhouse gas emissions and mitigation measures in Chinese agroecosystems. Agric Forest Meteor 142:270-277.

https://doi.org/10.1016/j.agrformet.2006.03.029

20. IPCC (2007) In: Metz B, Davidson OR, Bosch PR, Dave R, Meyer LA (eds), Climate Change 2007:

Mitigation. Contribution of Working Group III to the Fourth Assessment Report of the Intergovernmental Panel on Climate Change. Cambridge University Press, Cambridge

21. IPCC (2013) Climate Change 2013: The Physical Science Basis

22. Ji Y, Liu G, Ma J, Zhang GB, Xu H, Yagi K (2013) Effect of controlled-release fertilizer on mitigation of $\mathrm{N}_{2} \mathrm{O}$ emission from paddy field in South China: a multi-year field observation. Plant soil 371:473486. https://doi.org/10.1007/s11104-013-1700-6

23. Li RQ, Li YM, He JX, Li GC, Hao XC, Wang F (2011) Effect of N application rate on N utilization and grain yield of winter wheat. J Triti Crops 31:271-275. https://doi.org/10.7606/j.issn.10091041.2011.02.014

24. Li FM, Fan XL, Liu F, Wang Q (2004) Effects of controlled release fertilizers on $\mathrm{N}_{2} \mathrm{O}$ emission from paddy field. Chin J Appl Ecol 15:2170-2174. https://doi.org/10.13287/j.1001-9332.2004.0448 (in Chinese)

25. Lu M, Zhou XH, Luo YQ, Yang YH, Fang CM, Chen JK, Li B (2011) Minor stimulation of soil carbon storage by nitrogen addition: A meta-analysis. Agriculture Ecosystems Environment 140:234-244. https://doi.org/10.1016/j.agee.2010.12.010

26. Liu CY, Wang K, Meng SX, Zheng XH, Zhou ZX, Han SH, Chen DL, Yang ZP (2011) Effects of irrigation, fertilization and crop straw management on nitrous oxide and nitric oxide emissions from a wheat-maize rotation field in northern China. Agric Ecosyst Environ 140:226-233.

https://doi.org/10.1016/j.agee.2010.12.009

27. Liu XJ, Ju XT, Zhang FS, Pan JR, Christie P (2003) Nitrogen dynamics and budgets in a winter wheatmaize cropping system in the North China Plain. Field Crop Res 83:111-124.

https://doi.org/10.1016/S0378-4290(03)00068-6

28. Liu ZX, Gao F, Yang JQ, Zhen XY, Li Y, Zhao JH, Li JR, Qian BC, Yang DQ, Li XD (2019a)

Photosynthetic Characteristics and Uptake and Translocation of Nitrogen in Peanut in a WheatPeanut Rotation System Under Different Fertilizer Management Regimes. Front. Plant Sci 10:86. doi:10.3389/fpls.2019.00086

29. Liu ZX, Gao F, Liu Y, Yang JQ, Zhen XY, Li XX, Li Y, Zhao JH, Li JR, Qian BC, Li XD, Yang DQ (2019b) Timing and splitting of nitrogen fertilizer supply to increase crop yield and efficiency of nitrogen utilization in a wheat-peanut relay intercropping system in China. The Crop Journal 7:101-112. https://doi.org/10.1016/j.cj.2018.08.006 
30. Liang R, Liu MZ (2006) Preparation and properties of a double-coated slow-release and waterretention urea fertilizer. J Agric Food Chem 54:1392-1398. https://doi.org/10.1021/jf052582f

31. Mctaggart IP, Tsuruta $H$ (2003) The influence of controlled release fertilizers and the form of applied fertilizer nitrogen on nitrous oxide emission from an andosol. Nutr Cycl Agroecosyst 67:47-54. https://doi.org/10.1023/A:1025108911676

32. Ma SY, Liu YN, Wang YQ, Qin YN, Liu HL, Peng ZP (2015) Study on the characters of living condition and nutrient balance of high-yield wheat and maize rotation system in Hebei province. J Agric Univ 38:8-13. https://doi.org/10.13320/j.cnki.jauh.2015.0002 (In Chinese, with English abstract)

33. Peng SZ, Hou HJ, Xu JZ, Mao Z, Abudu S, Luo YF (2011) Nitrous oxide emissions from paddy fields under different water managements in southeast China. Paddy Water Environ 9:403-411. https://doi.org/10.1007/s10333-011-0275-1

34. Rochette P, Worth DE, Lemke RL, McConkey BG, Pennock DJ, Wagner-Riddle C, Desjardins RJ (2008) Estimation of $\mathrm{N}_{2} \mathrm{O}$ emissions from agricultural soils in Canada: I. Development of a country-specific methodology. Can J Soil Sci 88:641-654. https://doi.org/10.4141/CJSS07025

35. Reay DS, Davidson EA, Smith KA, Smith P, Melillo JM, Dentener F, Crutzen PJ (2012) Global agriculture and nitrous oxide emissions. Nat Clim Change 2:410-416. https://doi.org/10.1038/nclimate1458

36. Ribaudo M, Hansen L, Livingston M, Mosheim R, Williamson J, Delgado J (2011) Nitrogen in agricultural systems: Implications for conservation policy. USDAERS Economic Research Report. http://dx.doi.org/10.2139/ssrn.2115532

37. Rustad LE, Campbell JL, Marion GM, Norby RJ, Mitchell MJ, Hartley AE, Cornelissen JHC, Gurevitch J, Gcte-News (2001) A meta-analysis of the response of soil respiration, net nitrogen mineralization, and aboveground plant growth to experimental ecosystem warming. Oecologia 126:543-562. https://doi.org/10.1007/s004420000544

38. Shi Y, Wu W, Meng F, Zhang Z, Zheng L, Wang D (2013) Integrated management practices significantly affect $\mathrm{N}_{2} \mathrm{O}$ emissions and wheat-maize production at field scale in the North China Plain. Nutrient cycling in agroecosystems 95:203-218. https://doi.org/10.1007/s10705-013-9558-9

39. Smith KA, McTaggart IP, Tsuruta $\mathrm{H}$ (1997) Emissions of $\mathrm{N}_{2} \mathrm{O}$ and $\mathrm{NO}$ associated with nitrogen fertilization in intensive agriculture, and the potential for mitigation. Soil Use Manage 13:296-304. https://doi.org/10.1111/j.1475-2743.1997.tb00601.x

40. Song L, Zhang Y, Hu C, Zhang X, Dong W, Wang Y, Qin S (2013) Comprehensive analysis of emissions and global warming effects of greenhouse gases in winter wheat fields in the high-yield agro-region of North China Plain. Chin J Eco-Agric 21:297-307

41. Snyder CS, Bruulsema TW, Jensen TL, Fixen PE (2009) Review of greenhouse gas emissions from crop production systems and fertilizer management efects. Agric Ecosyst Environ 133:247-266. https://doi.org/10.1016/j.agee.2009.04.021

42. Scheer C, Grace PR, Rowlings DW, Payero J (2012) Nitrous oxide emissions from irrigated wheat in Australia: impact of irrigation management. Plant Soil 359:351-362. 
https://doi.org/10.1007/s11104-012-1197-4

43. Smith KA, Thomson PE, Clayton H, McTaggart IP, Conen F (1998) Effect of temperature, water content and nitrogen fertilization on emissions of nitrous oxide by soils. Atmosphere Environ 32:3301-3309. https://doi.org/10.1023/A:1009781518738

44. Shaviv A (2001) Advances in controlled-release fertilizers. Adv Agron 71:1-49. https://doi.org/10.1016/S0065-2113(01)71011-5

45. Schuster M, Conrad R (1992) Metabolism of nitric oxide and nitrous oxide during nitrification and denitrification in soil at different incubation conditions. FEMS Microbia Ecal 101:133-143. https://doi.org/10.1111/j.1574-6941.1992.tb00007.x

46. Shoji S, Delgado J, Moiser A (2001) Use of controlled release fertilizers and nitrification inhibitors to increase nitrogen use efficiency and to conserve air and water quality. Commun Soil Sci Plant Anal 32:1051-1070. https://doi.org/10.1081/CSS-100104103

47. Singh S, Singh JS, Kashyap AK (1999) Methane flux from irrigated rice fields in relationto crop growth and N fertilization. Soil Biol Biochem 31:1219-1228. https://doi.org/10.1016/S00380717(99)00027-9

48. Venterea RT, Coulter JA (2015) Split application of urea does not decrease and may increase nitrous oxide emissions in rainfed corn. Agron J 107:337-348. https://doi.org/10.2134/agronj14.0411

49. Venterea RT, Halvorson AD, Kitchen N, Liebig MA, Cavigelli MA, Grosso SJD, Motavalli PP, Nelson KA, Spokas KA, Singh BP, Stewart CE, Ranaivoson A, Strock J, Collins H (2012) Challenges and opportunities for mitigating nitrous oxide emissions from fertilized cropping systems. Front Ecol Environ 10:562-570. https://doi.org/10.1890/120062

50. Wang FH, He ZH, Sayre K, Li SD, Si JS, Feng B, Kong LG (2009) Wheat cropping systems and technologies in china. Field Crops Res 111:181-188. https://doi.org/10.1016/j.fcr.2008.12.004

51. Wang YY, Hu CS, Ming H, Zhang YM, Li XX, Dong WX, Oenema O (2013) Concentration profiles of $\mathrm{CH}_{4}, \mathrm{CO}_{2}$ and $\mathrm{N}_{2} \mathrm{O}$ in soils of a wheat-maize rotation ecosystem in North China Plain, measured weekly over a whole year. Agric Ecosyst Environ 164:260-272. https://doi.org/10.1016/j.agee.2012.10.004

52. Wang SJ, Luo SS, Li XS, Yue SC, Shen YF, Li SQ (2016) Effect of split application of nitrogen on nitrous oxide emissions from plastic mulching maize in the semiarid Loess Plateau. Agriculture Ecosystems Environment 220:21-27. https://doi.org/10.1016/j.agee.2015.12.030

53. Ward D, Kirkman K, Hagenah N, Tsvuura Z (2017) Soil respiration declines with increasing nitrogen fertilization and is not related to productivity in long-term grassland experiments. Soil Biology Biochemistry 115:415-422. https://doi.org/10.1016/j.soilbio.2017.08.035

54. Ye YS, Liang XQ, Chen YX, Liu J, Gu JT, Guo R, Li L (2013) Alternate wetting and drying irrigation and controlled-release nitrogen fertilizer in late-season rice. Effects on dry matter accumulation, yield, water and nitrogen use. Field Crops Res 144:212-224. https://doi.org/10.1016/j.fcr.2012.12.003

55. Yang XL, Sui P, Zhang M, Chen YQ, Gao WS (2014) Reducing agricultural carbon footprint through diversified crop rotation systems in the North China Plain. J Clean Prod 76:131-139. 
https://doi.org/10.1016/j.jclepro.2014.03.063

56. Yan XY, Du L, Shi S, Xing GX (2000) Nitrous oxide emission from wetland rice soil as affected by the application of controlled-availability fertilizers and mid-season aeration. Biol Fertil Soils 32:60-66. https://doi.org/10.1007/s003740000215

57. Yan X, Hosen Y, Yagi K (2001) Nitrous oxide and nitric oxide emissions from maize field plots as affected by $\mathrm{N}$ fertilizer type and application method. Biol Fert Soils 34:297-303. https://doi.org/10.1007/s003740100401

58. Zhong YM, Wang XP, Yang JP, Zhao X, Ye XY (2016) Exploring a suitable nitrogen fertilizer rate to reduce greenhouse gas emissions and ensure rice yields in paddy fields. Science of the Total Environment 565, 420-426. https://doi.org/10.1016/j.scitotenv.2016.04.167

59. Zou JL, Tobin B, Luo YQ, Osborne B (2018) Differential responses of soil $\mathrm{CO}_{2}$ and $\mathrm{N}_{2} \mathrm{O}$ fluxes to experimental warming. Agric Forest Meteor 259:11-22.

https://doi.org/10.1016/j.agrformet.2018.04.006

60. Zebarth BJ, Snowdon E, Burton DL, Goyer C, Dowbenko R (2012) Controlled release fertilizer product effects on potato crop response and nitrous oxide emissions under rain-fed production on a mediumtextured soil. Can J Soil Sci 92:759-769. https://doi.org/10.4141/cjss2012-008

61. Zhao XN, Hu KL, Li KJ, Wang P, Ma YL, Stahr K (2013) Effect of optimal irrigation, different fertilization, and reduced tillage on soil organic carbon storage and crop yields in the North China Plain. J Plant Nutr Soil Sci 176:89-98. https://doi.org/10.1002/jpln.201100353

\section{Figures}



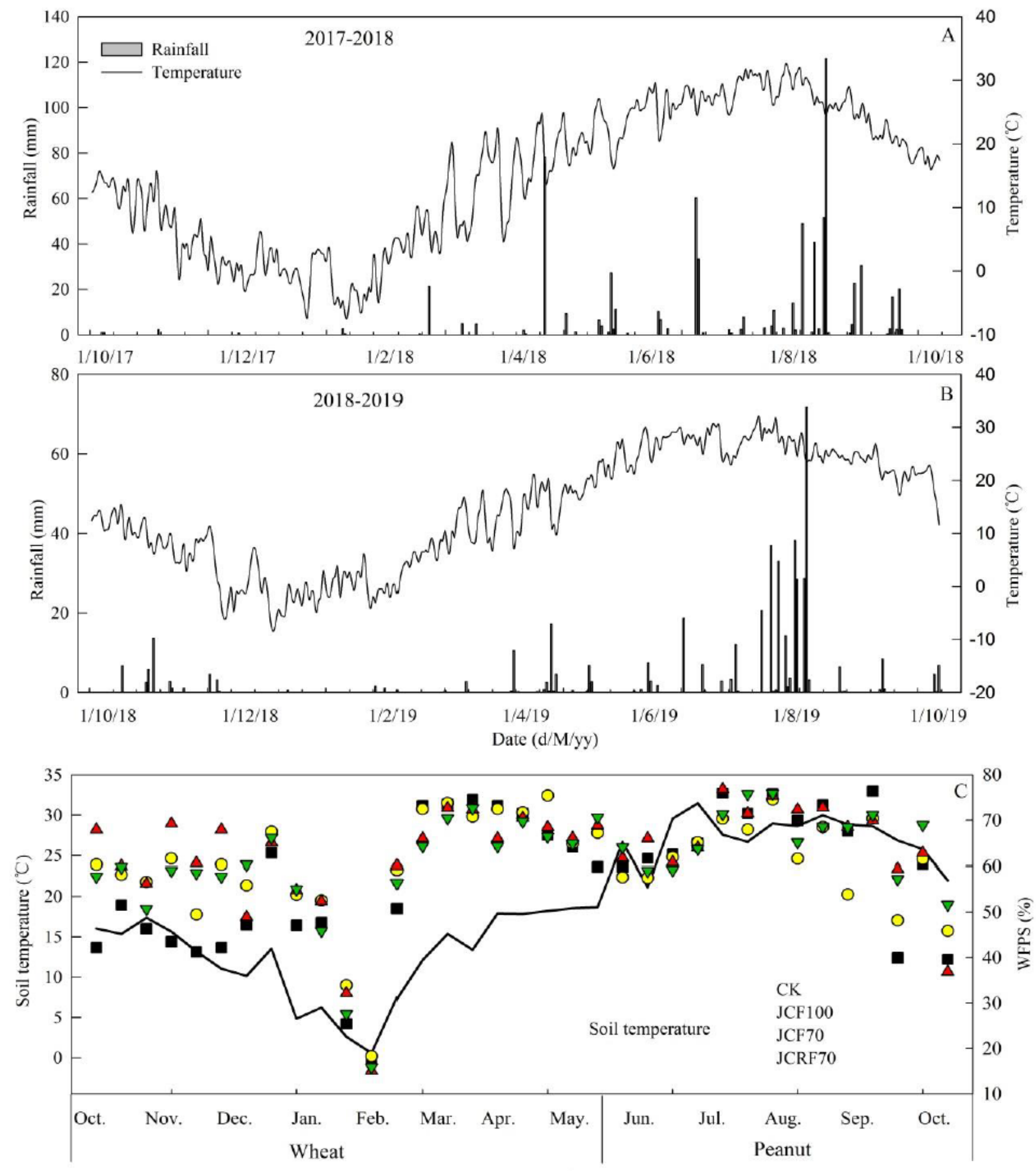

Months

\section{Figure 1}

Daily mean temperature, precipitation, Soil temperature, and WFPS during the wheat and peanut growing seasons in the field experiment. 


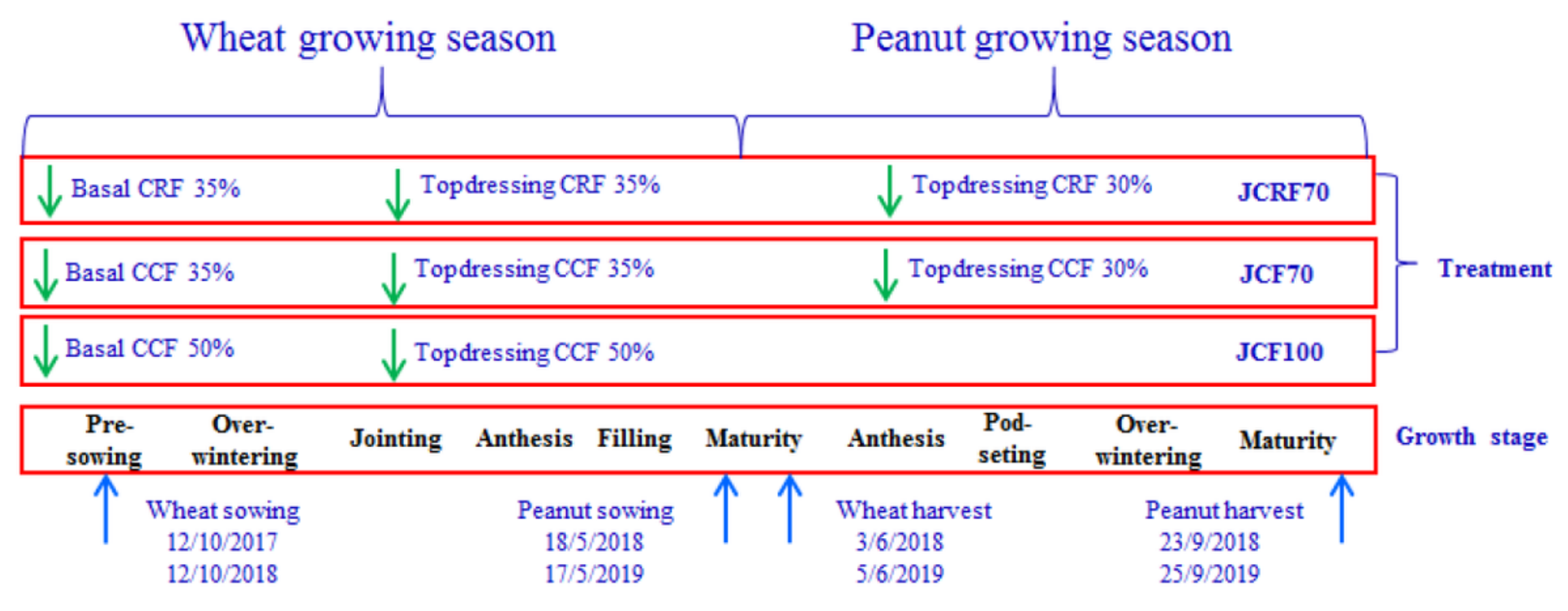

Figure 2

Schedule of field operations and cropping system used during the two seasons of GHG measurements.
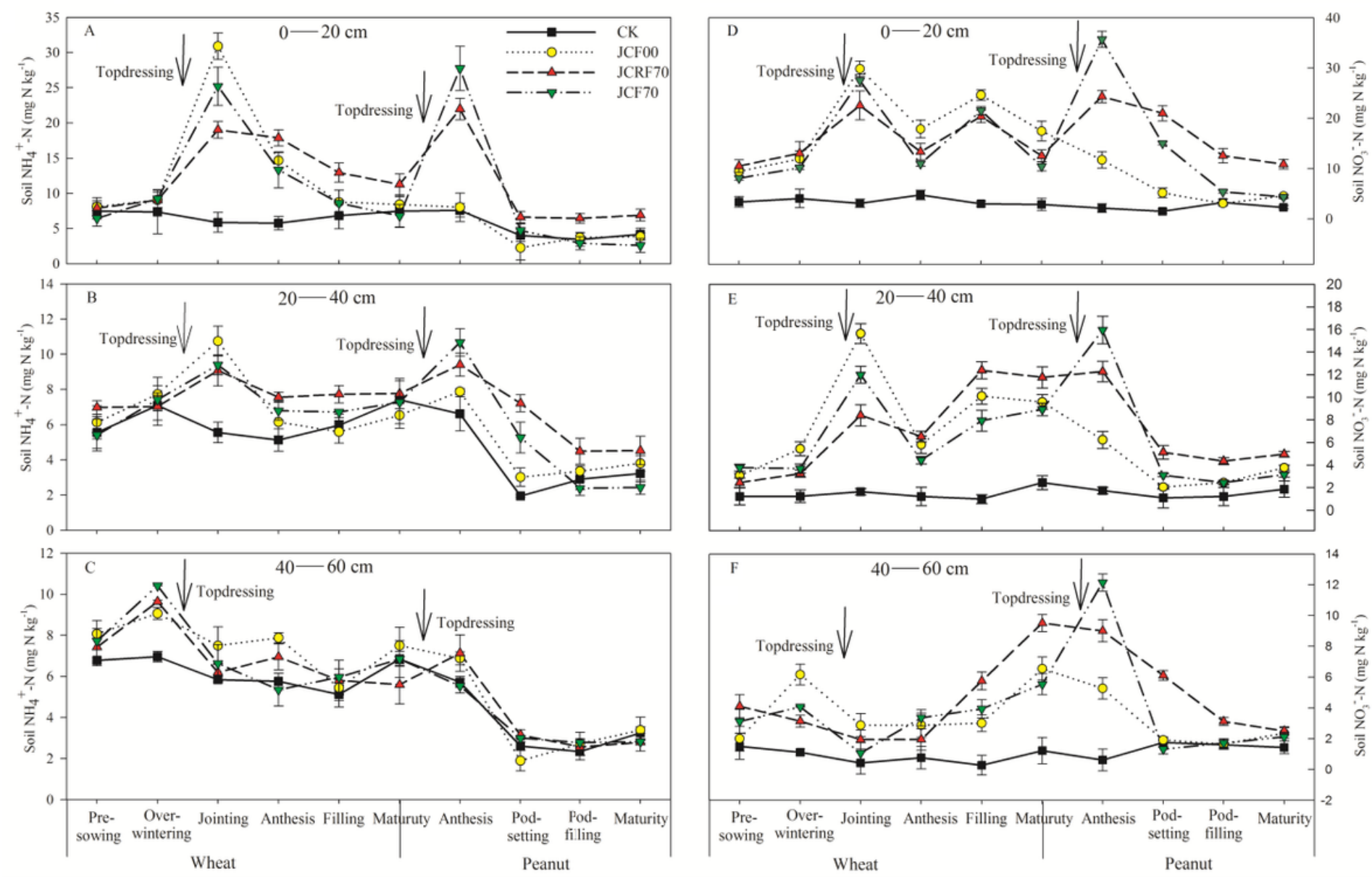

Growth stages

Figure 3 
Dynamics of soil NH+4-N and NO-3-N during the wheat and peanut growing seasons under different $\mathrm{N}$ application management during 2018-2019. A, B, and C represent the $0-20 \mathrm{~cm}, 20-40 \mathrm{~cm}$, and 40-60 $\mathrm{cm}$ of soil NH+4-N contents, respectively. D, E, and F represent the $0-20 \mathrm{~cm}, 20-40 \mathrm{~cm}$, and $40-60 \mathrm{~cm}$ of soil NO- 3-N contents, respectively. Error bars show the standard deviation of the mean. Solid line arrows indicate fertilisation.
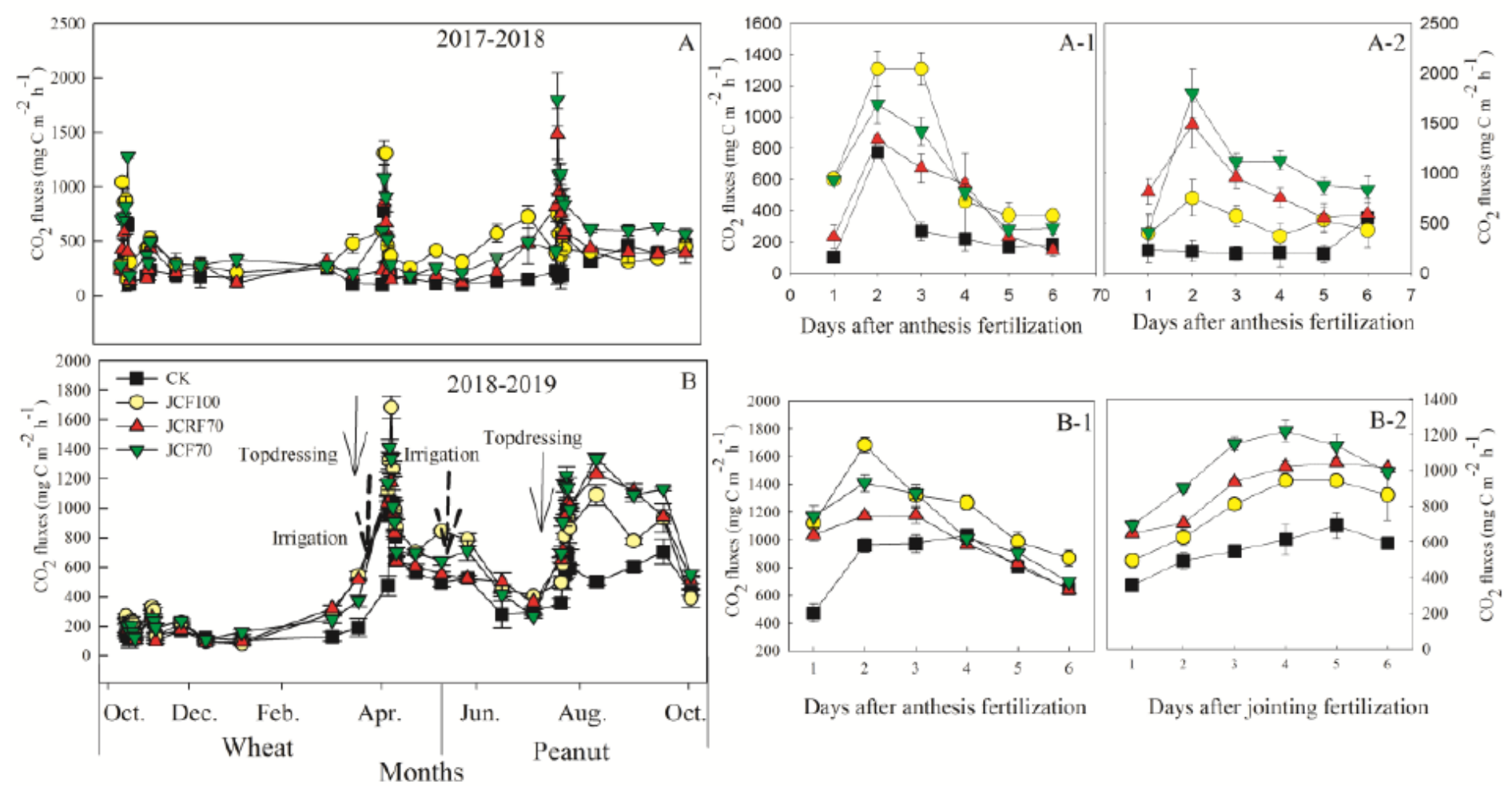

Figure 4

Seasonal variations of CO2 flux emission under different N fertiliser management from 2017 to 2019 . Error bars show the standard deviation of the mean. Solid line arrows indicate fertilisation, and dotted line arrows indicate irrigation. 

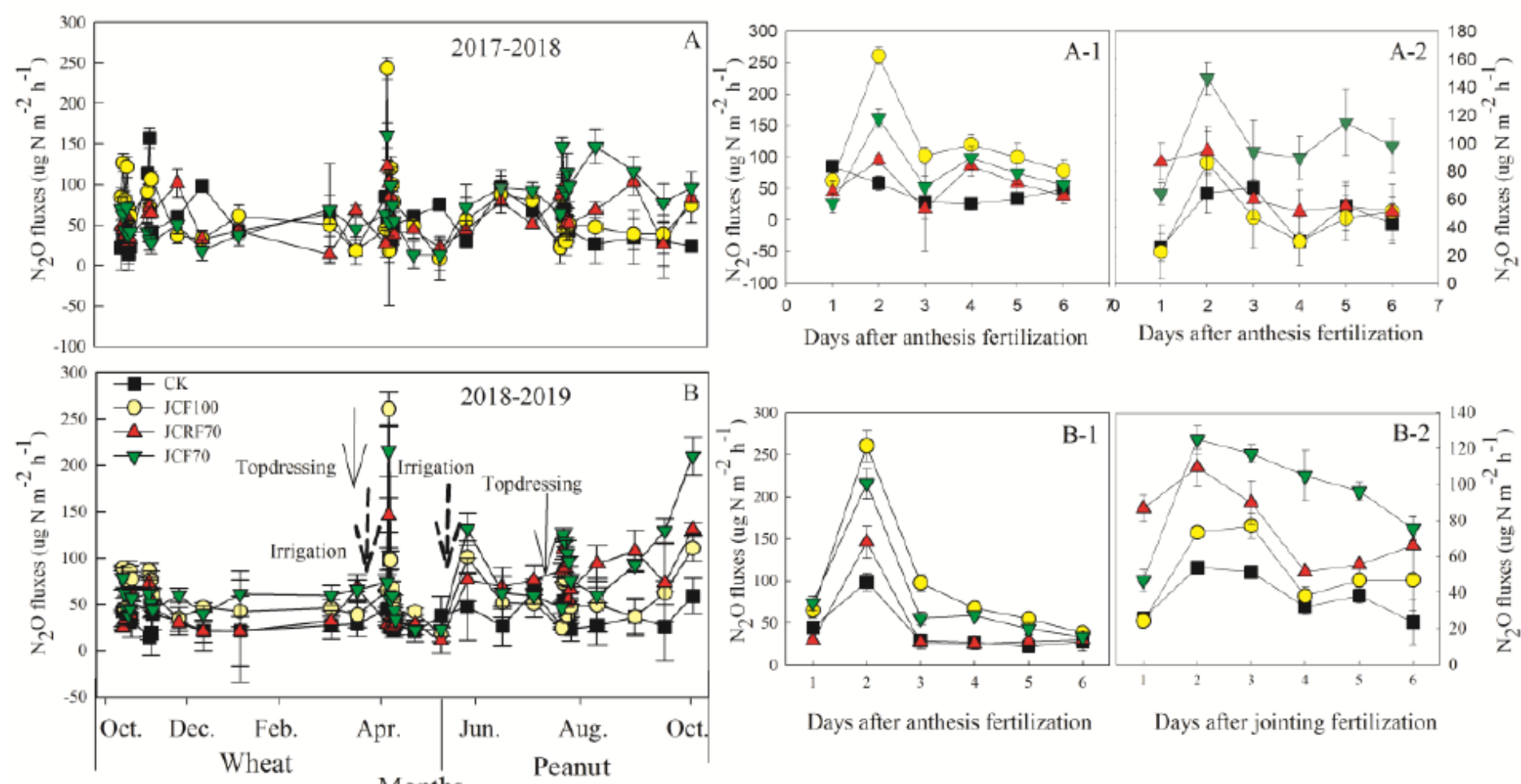

Days after anthesis fertilization

Days after jointing fertilization Months

Figure 5

Seasonal variations of N2O flux emission under different N fertiliser management from 2017 to 2019. Error bars represent the standard deviation of the mean. Solid line arrows indicate fertilisation, and dotted line arrows indicate irrigation. 

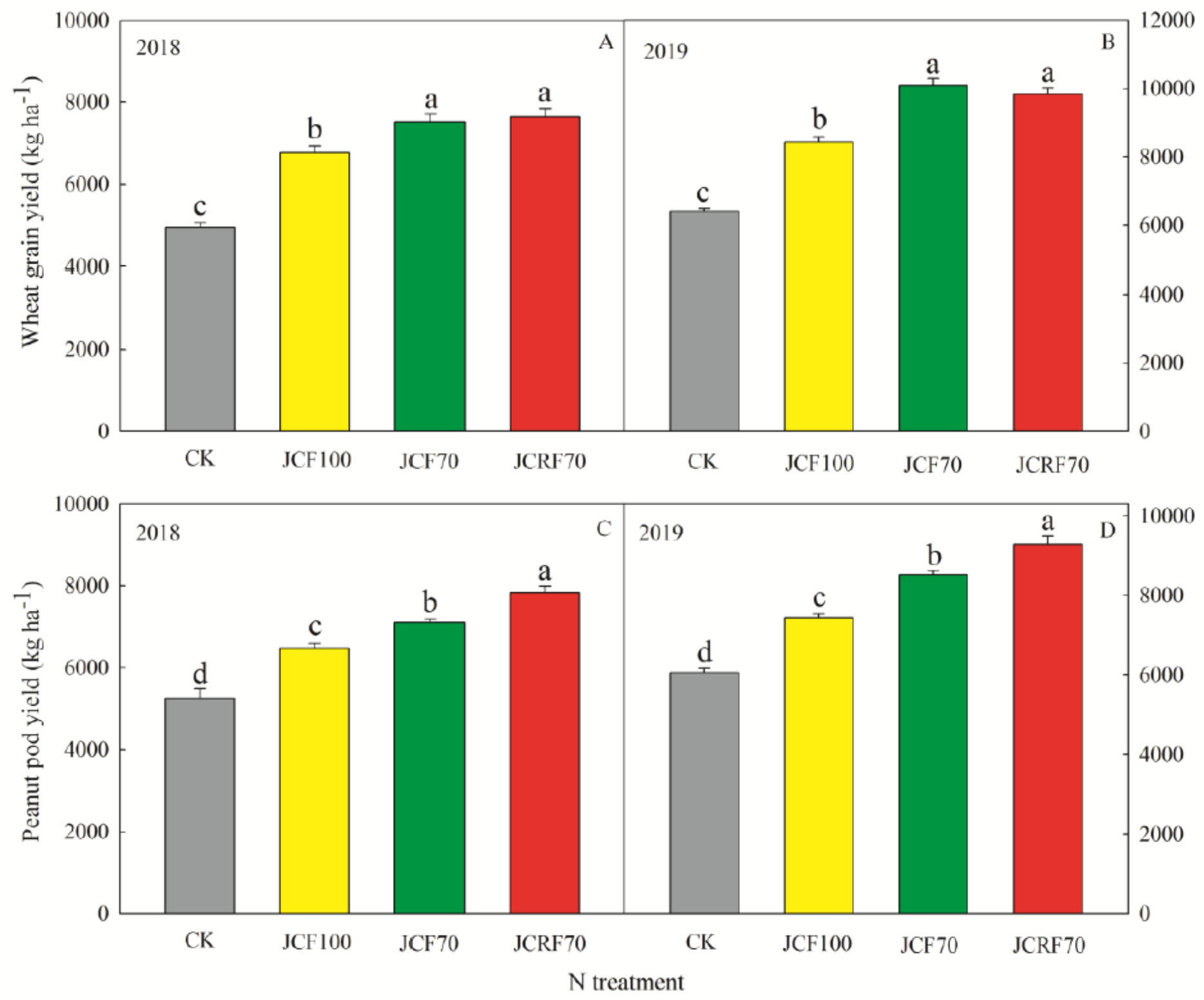

Figure 6

The wheat grain yield and peanut pod yield under different $\mathrm{N}$ application management from 2017 to 2019. Error bars show the standard deviation of the mean. Different lowercase letters indicate statistical differences among the treatments $(P<0.05)$, according the LSD test. 